\title{
A dynamic approach to real-time performance measurement in design projects
}

\author{
Skec, Stanko; Cash, Philip; Storga, Mario
}

Published in:

Journal of Engineering Design

Link to article, DOI:

$10.1080 / 09544828.2017 .1303665$

Publication date:

2017

Document Version

Peer reviewed version

Link back to DTU Orbit

Citation (APA):

Skec, S., Cash, P., \& Storga, M. (2017). A dynamic approach to real-time performance measurement in design projects. Journal of Engineering Design, 255-286. https://doi.org/10.1080/09544828.2017.1303665

\section{General rights}

Copyright and moral rights for the publications made accessible in the public portal are retained by the authors and/or other copyright owners and it is a condition of accessing publications that users recognise and abide by the legal requirements associated with these rights.

- Users may download and print one copy of any publication from the public portal for the purpose of private study or research.

- You may not further distribute the material or use it for any profit-making activity or commercial gain

- You may freely distribute the URL identifying the publication in the public portal

If you believe that this document breaches copyright please contact us providing details, and we will remove access to the work immediately and investigate your claim. 


\section{A DYNAMIC APPROACH TO REAL TIME PERFORMANCE MEASUREMENT IN DESIGN PROJECTS}

Stanko Škec ${ }^{* 1}$, Philip Cash², Mario Štorga ${ }^{1,3}$

${ }^{1}$ Faculty of Mechanical Engineering and Naval Architecture, University of Zagreb,

Croatia

${ }^{2}$ Department of Management Engineering, DTU, Denmark

${ }^{3}$ Department of Business Administration, Technology and Social Sciences, Lulea University of Technology, Sweden

To cite this article: Stanko Škec, Philip Cash \& Mario Štorga (2017): A dynamic approach to real-time performance measurement in design projects, Journal of Engineering Design, 28(4), pp. 255-286.

To link to this article: $\underline{\text { http://dx.doi.org/10.1080/09544828.2017.1303665 }}$

\section{Corresponding author:}

Škec Stanko

Faculty of Mechanical Engineering and Naval Architecture

University of Zagreb,

Ivana Lučića 5

10000 Zagreb, Croatia

Telephone: +385-1-6168-431

Email: stanko.skec@fsb.hr 


\title{
A Dynamic Approach to Real Time Performance Measurement in Design Projects
}

\begin{abstract}
Recent developments in engineering design management point to the need for more dynamic, fine-grain measurement approaches able to deal with multi-dimensional, cross-level process performance in product design. Thus, this paper proposes a new approach to the measurement and management of individual and teamwork performance in engineering design projects. This integrates multiple, previously disparate, aspects of design management and performance measurement theory in a single framework. Further, a fully realised performance measurement approach is developed, which complements existing management strategies. This framework is synthesised from an extensive review and illustrated via an in-depth case study. As such, this work contributes to performance measurement theory in engineering design and has significant implications for both engineering design research and industry.
\end{abstract}

Keywords: design management; design process; design behaviour; performance metrics

\section{Introduction}

There is a substantial gap between theory and practice in the measurement and management of design work. Specifically, recent empirical studies of engineering design highlight its multi-dimensional nature and the current lack of measurement approaches in this context (Wasiak et al. 2011; Robinson 2012). Further, researchers have criticised the dominant focus on outcome-based tangible measures such as financial/technical performance, and adherence to schedule (Blindenbach-Driessen, Van Dalen, and Van Den Ende 2010). Here, consideration of intangible aspects is critically lacking; particularly, as these aspects give direct and responsive insight into emergent design processes, such as knowledge sharing (McMahon, Lowe, and Culley 2004; Kleinsmann and Valkenburg 2008) or creativity and innovativeness (Dorst and 
Cross 2001). Thus, significant questions remain in how to effectively integrate these intangible aspects into measurement practice.

Current individual/team level performance measurement approaches have been consistently shown to be theoretically incomplete in the context of engineering design (MacBryde and Mendibil 2003; Yin, Qin, and Holland 2011; Sivasubramaniam, Liebowitz, and Lackman 2012). Specifically, they are often domain specific, low granularity (in terms of the duration of the activities monitored), static, and focused on tangible outputs (Blindenbach-Driessen, Van Dalen, and Van Den Ende 2010; Thamhain 2013). Further, these approaches use retrospective data, aggregated at the organisational level (e.g. Henttonen, Ojanen, and Puumalainen 2016), to examine unidimensional relationships between engineering design performance constructs (Birdi, Leach, and Magadley 2016). Thus there is a disconnect between measurement and theory, around the inclusion of dynamic intangible elements at the individual/team level (Redelinghuys and Bahill 2006; Yang, Dong, and Helander 2012). For example, MacBryde and Mendibil (2003) emphasized the need to monitor the dynamic interrelations between tasks, team characteristics, and team processes within the organizational context; identifying a number of drivers related to dynamic and intangible aspects of the engineering design processes. These numerous intangible variables have been described in fields including intellectual capital, innovation management, knowledge management, and engineering design (e.g. González-Loureiro and Figueroa Dorrego 2012; Visnjic et al. 2014). However, these variables have not been coherently integrated in current engineering design performance measurement models or tools applicable to the individual/team level (Dul and Ceylan 2014). This is specifically highlighted by Birdi et al. (2016), who calls for research to integrate the multiple dimensions contributing to engineering design work at this level. For example, McComb et al. (2015) discuss how a team responds to changes in design task and how to make it more resilient to these changes. However, this has not been reflected in a corresponding development of measurement theory, which has tended to focus on increasingly refined tangible approaches e.g. Gopsill et al.'s (2014) work on real-time sampling of information objects. These deficits in current approaches are crystallised in the recent work of Dewangan and Godse (2014), which excludes the individual/team level. Thus, integration of lower level intangible elements at the individual/team level is a key research area (Robinson, 2012). 
In this context, Aurisicchio et al. (2009), amongst others (Badke-Schaub, Neumann, and Lauche 2011; Cash, Hicks, and Culley 2015), specifically highlight the importance of interpersonal relationships in teamwork culture and performance, while Yeo (2002) and Cooke-Davis (2002) emphasise the role of human factors. Ultimately this leaves an open question in how to integrate intangible elements from multiple literatures in a cohesive engineering design measurement approach. This paper responds to this question by developing such a framework.

At the individual/team level interdependence and high levels of connectivity between individuals means that elements of intellectual capital, knowledge management, and engineering design are all significantly related to performance (Liu, Chen, and Tao 2015; Bammens 2016). For example, Snider et al. (2016) highlight the importance of individual's creative behaviour in contributing to engineering design performance. Further, McCarthy et al. (2006) highlight the non-linear emergence of these processes including knowledge sharing (Valkenburg and Dorst 1998), and learning (Smith, Hedley, and Molloy 2009). As such, any new approach for measuring and managing the dynamic evolution of intangible elements must bring together these diverse perspectives. This must also be complementary to concurrent efforts to create more dynamic tangible approaches (Gopsill et al. 2014; Wasiak et al. 2011), as well as higher level performance indicator based perspectives (Taylor 2016). In response, this paper describes a theoretical framework that integrates these elements, and operationalizes them in a real-time measurement approach at the individual/team level. Thus this work contributes to both engineering design performance measurement theory and practice, and is a direct response to calls for empirical investigation of engineering design projects and processes that integrate individual and team levels (Bissola, Imperatori, and Colonel 2014).

The remaining paper is structured as follows. First, the theoretical background in engineering design performance measurement is elucidated. Second, the proposed measurement approach is outlined theoretically and practical implementation is described. Third, a case study is used to illustrate the implementation and impact of the proposed approach. Finally, implications are outlined for both theory and practice. 


\section{Theoretical Background}

Performance indicators form the basis for process measurement, and are thus critically linked to effective management and overall success (O’Donnell and Duffy 2005; Molina-Castillo and Munuera-Alemán 2009). This is achieved by linking measures, grounded in theory, to objectives at various organisational levels (Takim and Akintoye 2002). However, three major issues have been highlighted by Gries and Restrepo (2011), which are particularly relevant to the inclusion of intangibles:

1. Heterogeneous application and data landscapes: synthesis, synchronisation, and analysis become problematic when using multiple varied sources of data.

2. Performance indicator inflation: measuring and monitoring many indicators that are not aligned with strategy.

3. Pseudo-accuracy: the first two issues create a situation where undue weight is given to measures of tangible aspects leading to inaccuracies and unconvincing results.

Based on these issues it is possible to define three characteristics that must be fulfilled by any new approaches aiming to incorporate intangibles. These build on the fundamental logic that 'you can't manage well what you can't measure right' (CruzCázares, Bayona-Sáez, and García-Marco 2013):

1. In contrast to lagging monetary measures, non-monetary measures provide a leading input orientated perspective.

2. High measurement frequency and streamlined analysis allow for dynamic monitoring and real-time feedback on smaller scale processes.

3. Measures for intangible elements, offer the possibility of operationally linking organisation level measures to individual/team level processes.

Based on these characteristics it is necessary to create a framework of leading indicators reflecting intangible elements at the individual/team level, in order to provide a more accurate view of real-time engineering design process dynamics and address the above highlighted issues.

In this context intangible engineering design performance variables at the individual/team level are scarce and scattered across different research fields (Dumay, 2014). For example, McComb et al. (2015) focus on team performance in terms of 
interaction between individuals and their problem solving styles, while Kleinsmann et al. (2012) focus on the development of design collaboration skills. This diversity of focus is partially rooted in the breadth of areas needing to be considered. However, a large number of variables, as well as their basic associations, have already been described in the Intellectual Capital (IC) literature, hence this is used as the starting point for integration in this work. The IC literature brings together a wide range of concepts beyond the scope of engineering design management alone, as illustrated in the recent review by Aisenberg Ferenhof et al. (2015). However, in the context of engineering design performance measurement, IC provides the basis for developing measures for intangible elements, bringing together many of the individual/team level factors excluded from prior performance measurement frameworks (Sivasubramaniam, Liebowitz, and Lackman 2012). Further, these allow for the integration of insights from other related fields such as knowledge management, innovation management and engineering design.

Integrating these various research areas into an engineering design management frameworks gives the potential for additional insight into the intangible elements of engineering design work (Sivasubramaniam, Liebowitz, and Lackman 2012). However, how to effectively measure the relevant intangible elements is an open question (Dumay, 2009). In the IC literature four general measurement approaches are described, which could be used to inform developments in the engineering design domain: Direct Intellectual Capital (DIC) (e.g. Brooking 1997), Market Capitalization Methods (MCM) (e.g. Kujansivu \& Lönnqvist 2007), Return On Assets (ROA) (e.g. Pulic 2000), ScoreCard (SC) (e.g. Edvinsson 1997).

As noted in the introduction, measures for tangible elements alone cannot give a full picture of engineering design performance, and suffer from limitations such as lag and a limited dynamic response (Artz et al. 2010). As ROA and MCM primarily build on this type of measure they are suited to integration with engineering design performance measurement frameworks at higher organisational levels, where dynamic individual/team behaviour is less directly influential (Tan, Plowman, and Hancock 2008). Thus they leave a significant gap at lower levels and in the management of dynamic intangible aspects, particularly with respect to engineering design processes. In contrast, DIC and SC methods embrace a broader perspective based on qualitative 
results (Sveiby 2010), making them more suited to integration with engineering design performance measurement frameworks across levels. Further, by building on a bottomup perspective they are able to provide results faster and with more precision. However, they are still far from real-time and are highly context dependant (Sveiby 2010), making them unsuitable for monitoring dynamic fine-grain processes (Cash et al. 2015).

Collectively these approaches suffer a common drawback of lagging evaluation (Bratianu and Orzea 2013), i.e. a reliance on coarse-grain periodic measurements (Mouritsen, Bukh, and Marr 2004). This both delays results and precludes the monitoring of the dynamic processes fundamental to engineering design work (Dorst and Cross 2001; Charnley, Lemon, and Evans 2011). Based on these limitations it is possible to define the theoretical characteristics of a framework integrating intangible elements from across fields (Verbano and Crema 2014; Giuliani 2014) into the context of engineering design process performance measurement. Each characteristic is examined in the following subsections:

1. Fine-grain Measurement: including individual/team level engineering design work.

2. Dynamic Measurement: including real-time measures able to trace dynamic finegrain processes.

3. Inclusion of intangibles: linking measures of intangible aspects to extant approaches.

\subsection{Fine-grain Measurement}

Most current approaches focus on organisation and project level performance measurement via e.g. financial or other Key Performance Indicators (KPI's) (Parmenter 2010). See for example, the recent work of Taylor (2016) on KPI selection. These systems of KPI's provide an effective means of measurement where long-term retrospective assessment of performance is the aim (Fernandes, Raja, and Whalley 2006). This characterisation also applies to KPI application at the individual/team level, where periodic assessments are used to reflect on e.g. human resources or know-how (Gates and Langevin 2010). However, the coarse-grain periodicity of these measures means they do not directly examine many of the processes that dominate performance at the individual/team level. One reason for this lack is that individual/team level 
performance indicators have been little examined in practice and are often described without concrete metrics. For example, in the context of engineering design performance many existing indicators are based on quantitative survey studies, which focus on non-operationalized variables at higher organisational levels (e.g. Dewangan and Godse 2014). Thus, the level of granularity at which these variables are defined is not compatible with their implementation as indicators at the individual/team level (Robinson 2012). This is not to say they do not provide a basis for measurement at this lower level, but that there is significant work still needed to operationalize them as true indicators in this context. Accordingly, Ojanen \& Vuola (2005) and Reid \& de Brentani (2015) highlight the importance of developing bottom-up insight. As such, current approaches to engineering design performance measurement only partially reflect process dynamics at the individual/team level.

\subsection{Dynamic Measurement}

A number of research works have linked intangible variables to product development projects (Chen, Liu, Chu, and Hsiao, 2014; Hsu and Fang, 2009; Turner, Maylor, and Swart, 2015). However, this has not resulted in a corresponding development in engineering design performance measurement. This is despite repeated calls for research in this area. For example, Robinson (2010) and Cash et al. (2015) both emphasized the need to better understand process dynamics of intangible factors in engineering design teams. Similarly, Vuolle et al. (2009) criticized the generality of indicators and tangible focus of existing development project performance models. Finally, Blindenbach-Driessen et al. (2010) highlighted the limitations introduced by bias (Ernst 2002), subjectivity, and retrospective assessment (Podsakoff et al. 2003) in current performance frameworks that do not take a dynamic process view.

In the dynamic paradigm there is a need for indicators able to incorporate both social and technical perspectives (Gopsill et al. 2014), and able to react to the rapid changes found in processes at the individual and team level (Cash and Štorga 2015; Valkenburg and Dorst 1998). As such, a bottom-up approach able to longitudinally aggregate measurement would both give deeper insight into individual/team performance and allow for flexibility in application across organisational levels. Such an approach would necessarily bring together quantitative real-time data on activities and intangible process elements with higher-level measures. This would complement existing lagging 
indicators at the organisational level (Taylor 2016), and would extend current engineering design performance measurement frameworks to be compatible with the requirements outlined at the start of Section 2.

\subsection{Inclusion of Intangibles}

Connecting performance indicators across tangible and intangible aspects is key to completing any cohesive engineering design performance measurement approach. However, due to the complexity involved with evaluating intangible factors, conventional methods are not able to meet the needs of decision makers and project managers in practice (Montemari and Nielsen 2013). In particular, current methods focus almost exclusively on quantitative data (e.g. financial performance or adherence to schedule (Blindenbach-Driessen, Van Dalen, and Van Den Ende 2010)) and adopt a "measurement on hold" approach. Such approaches give static indicators, measured on an annual or semi-annual basis at the organizational level. These are at odds with the active monitoring of the intangible elements required to understand interactions within fine-grain, dynamic engineering design processes (Cash et al. 2015). Therefore connection across this boundary must be considered in performance measurement. In particular, Spitzer (2009) discusses how linking can be done, as a part of a changing paradigm in performance measurement. This highlights the need to combine both tangible and intangible aspects in a cohesive framework (Pollack 2007) tailored to the engineering design context. Coupling of these perspectives has also been highlighted in a number of research studies e.g. Liu, Chen, and Tao (2015) who analysed the influence of collective behaviour and information exchange on performance in product development teams. However, these studies are typically survey based and focused on a single measurement dimension, and thus do not meet the other two measurement characteristics outlined in this section.

Further, while outcome-based tangible indicators provide insight on final outcomes, process-based intangible ones serve as leading indicators and allow managers to obtain information about certain aspects of performance in advance. However, many current performance measures lack the specificity required for application in the fine-grain context of real-world design teams (Vuolle, Lönnqvist, and Meer 2009). As such, linking intangible and tangible requires a framework where leading and lagging measures can be aligned (Spitzer, 2009). This connection offers a more complete view 
of team (MacBryde and Mendibil 2003) and process performance (Syamil, Doll, and Apigian 2004), as well as an understanding of cause-effect relationships between intangible and tangible factors. Thus, to introduce new measures of intangible elements into existing engineering design performance measurement, it is necessary to develop both theory and practical procedures for connected data acquisition, analysis, and interpretation.

\section{Extending Current Approaches}

This section first outlines the guiding theoretical framework before detailing the development of the practical measurement approach.

\subsection{Theoretical Framework}

Integrating the state of the art evaluation of intangible elements from across fields, but primarily building on Sivasubramaniam et al. (2012) and Aisenberg Ferenhof et al. (2015), it is possible to identify a gap in current engineering design performance measurement approaches when related to the framework provided by Dewangan and Godse (2014). Specifically, there is a need for a theoretical framework that integrates intangible elements, and operationalizes them in a real-time measurement approach at the individual/team level. The gap in current approaches is illustrated in Figure 1.

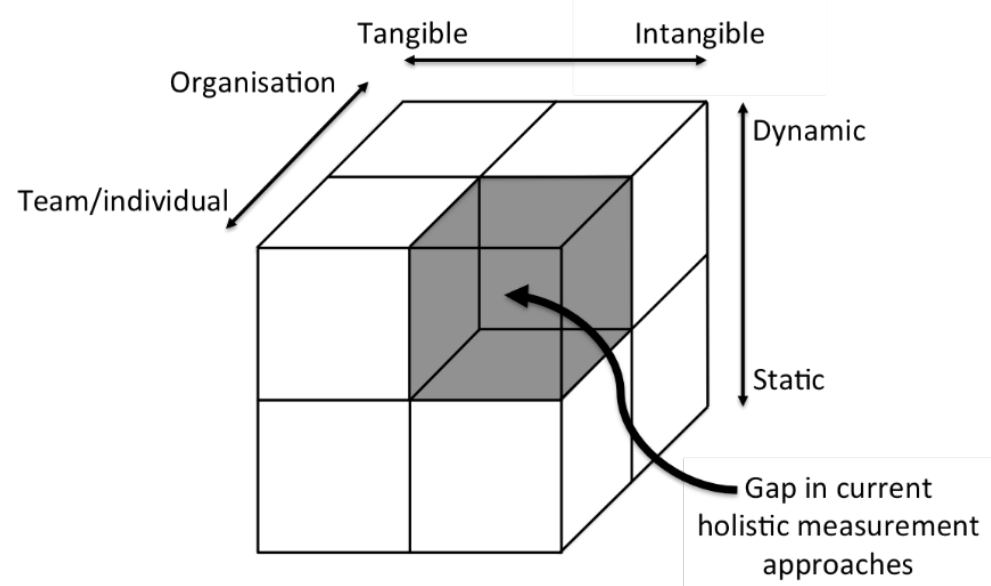

Figure 1: Aspects of engineering design performance measurement

The following sections address this gap by synthesising a measurement approach, together with the supporting development of measurement theory in this area. The goal 
of such synthesis is to provide a more cohesive measurement framework in this extended context. The extended measurement framework is illustrated in Figure 2.

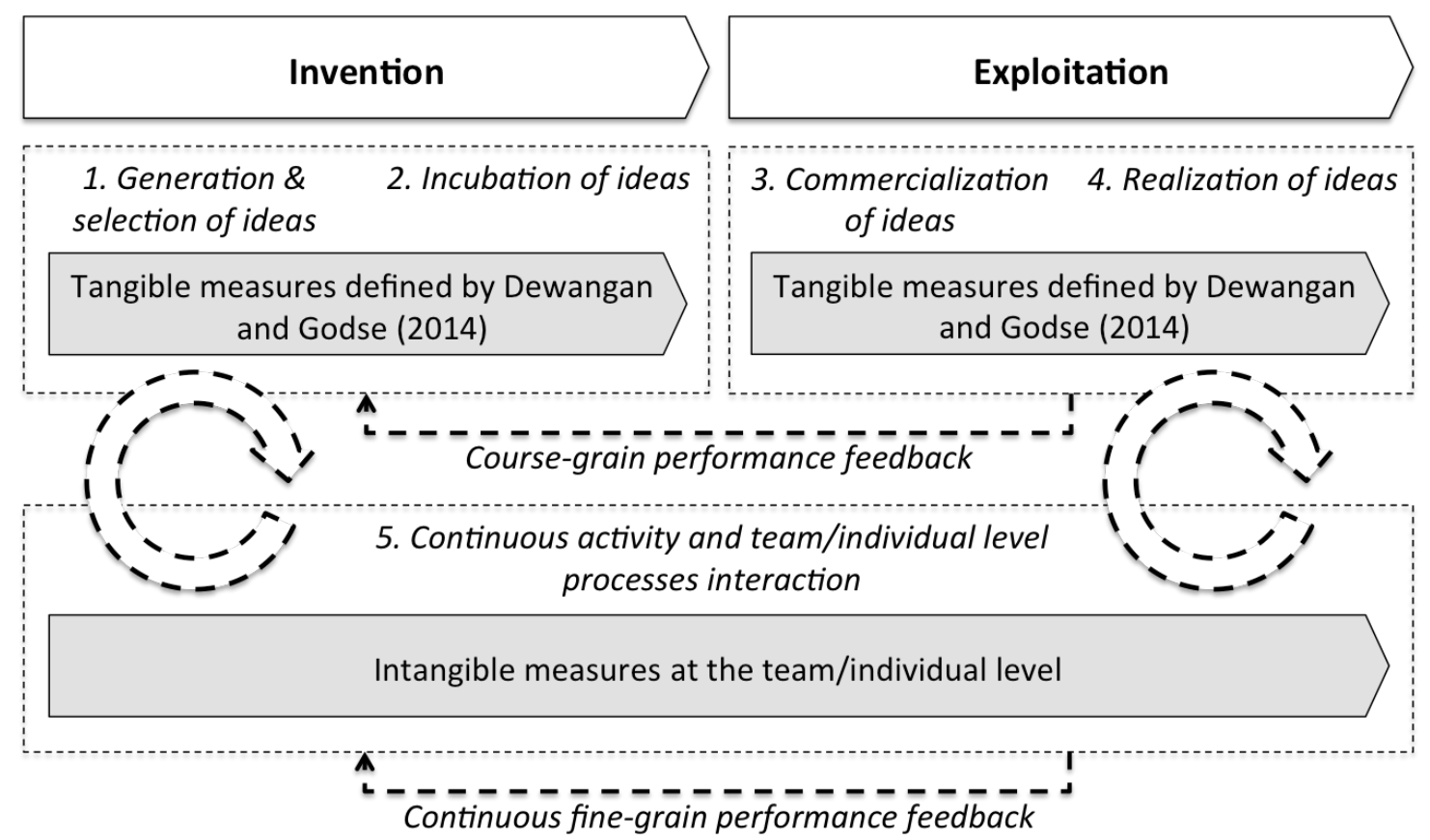

Figure 2: An extended view of engineering design project performance measurement including team/individual level interactions

\subsection{Development of the Measurement Approach}

In the following subsections the phases involved in developing the proposed measurement approach are described. These are summarised in Figure 3, which outlines each phase of synthesis along with explicit inclusion/exclusion criteria.

\subsubsection{Initial Identification of Indicators}

In order to complement organisation focused frameworks, indicators at the individual/team level must be established. Although there is research in this area there are few validated measures fitting the criteria outlined in Section 2. As such, there was a need to first identify indicators before developing these into fully specified measures. A structured review of the intellectual capital measurement, innovation management, knowledge management, and engineering design process performance literature was used to identify more than 400 possible indicators (Figure 3). 


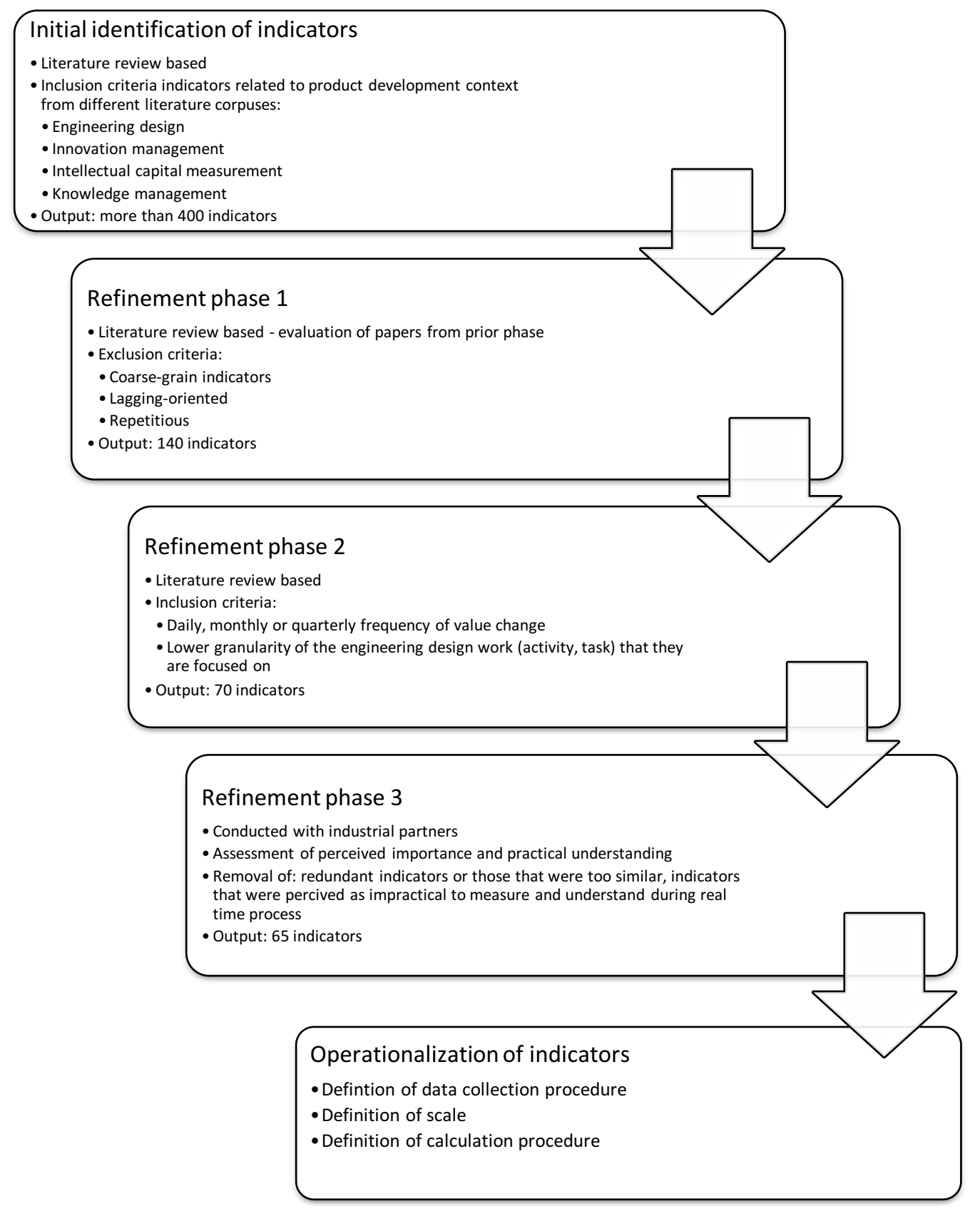

Figure 3: Development of list of indicators for intangible aspects

This adopted a systematized mapping type approach (Grant and Booth 2009) that was used to identify indicators from a range of fields. This combines systematic and critical elements in order to map and characterise items from a wide range of sources where full systematic review would not be feasible - due to the wide spread of indicators across fields (Grant and Booth 2009). As a starting point key journals in each field were identified (engineering design - Design Studies, Journal of Engineering Design; innovation management - Journal of Product Innovation Management, Technovation; 
intellectual capital - Journal of Intellectual Capital; Measuring Business Excellence; knowledge management: Journal of Knowledge Management, Knowledge Management Research \& Practice) and initial keywords ("intellectual capital" or its constituent parts such as e.g. "communication" coupled with "performance", "performance measurement", "performance indicators") were used to search full papers in the time range from 2000-2016. This initial starting point then allowed for successive iteration of keywords, and searching through citations and references to build an extensive mapping of key literature on indicators for intangible aspects in each field.

\subsubsection{Refinement Phase 1}

Based on the indicators identified in the prior phase initial exclusion criteria were applied: item was coarse-grain, item was lagging, item was repetitious, item was not relevant to product development. Examples of excluded indicators were: amount of money spent on competency improvement for the whole organization and education level of employees (coarse grain), or average income from patented products and processes and number of new processes incorporated in last 5 years (lagging).

In this context, the focus was on leading rather than lagging indicators able to be applied operationally i.e. related to dynamic design processes (Refinement phases 1 and 2 on Figure 3). Leading indicators are by definition input-oriented and thus difficult to measure. However, they are a key element in reacting to dynamic processes, particularly when these indicators are integrated with higher-level measures (Items 14, Figure 2). Finally, an important inclusion criteria at this stage was that each indicator taken forward had been independently associated with project performance. For example, Amabile (1988) highlights motivation as a key component of creativity, with people being most innovative during interesting, challenging, and enjoyable activities. Ensuring this connection between individual indicators and project performance was a key component in maintaining the theoretical robustness of the proposed approach. However, it is important to note that many of the leading indicators did not currently have defined measures (e.g. percentage of time team members spent on meetings).

After applying these exclusion criteria the list of indicators was reduced to 140, which were then grouped into eleven measurement areas based on a grounded assessment of their characteristics. These are defined in Table 1 together with the primary references 
for each area based on previous work done by Aisenberg Ferenhof et al. (2015), González-Loureiro \& Figueroa Dorrego (2012), and Verbano \& Crema (2014). Based on these measurement areas it was subsequently possible to define actionable measures (i.e. operationalized indicators with specific metrics) with respect to the time and granularity criteria summarised in Figure 2. The last column in Table 1 relates measurement areas with the four derived categories, and extends Dewangan and Godse's (2014) system of measurement into the intangible individual/team level domain. The four specific categories of indicators shown in Table 1 are:

1. Competence and knowledge development;

2. Communication and information exchange;

3. Innovativeness and ideation capability;

4. Motivation and satisfaction.

\subsubsection{Refinement Phase 2}

In this phase the 140 indicators were refined into 70 candidates. Here indicators were excluded based on applicability to: individual or team level, frequency of value change (daily, monthly, quarterly, annually), and granularity of the engineering design work that they are focused on (activity, task, phase, project, portfolio). To be included at this phase indicators needed to: change value on daily, monthly or quarterly basis (e.g. percentage of time spent on discussions), and be applicable to the lower granularity of engineering design work (e.g. percentage of time spent on ideation activities).

Table 1: Overview of measurement areas clustered with respect to Aisenberg Ferenhof et al. (2015)

\begin{tabular}{|c|c|c|}
\hline $\begin{array}{c}\text { Measurement } \\
\text { area }\end{array}$ & Description & $\begin{array}{c}\text { Categories of } \\
\text { indicators for } \\
\text { intangible aspects } \\
\end{array}$ \\
\hline \multicolumn{3}{|c|}{ Motivation } \\
\hline \multirow{2}{*}{$\begin{array}{l}\text { Work } \\
\text { motivation }\end{array}$} & $\begin{array}{l}\text { "Work motivation is a set of energetic forces that originate } \\
\text { both within as well as beyond an individual's being, to initiate } \\
\text { work-related behaviour and to determine its form, direction, } \\
\text { intensity, and duration." (Pinder 1998, p. 27) }\end{array}$ & \multirow{2}{*}{$\begin{array}{c}\text { Motivation and } \\
\text { satisfaction }\end{array}$} \\
\hline & $\begin{array}{l}\text { (Bontis and Fitz-enz 2002; Alwert, Bornemann, and Kivikas } \\
\text { 2004; F. Tunc Bozbura 2004; J. Chen, Zhu, and Xie 2004; F. } \\
\text { T. Bozbura, Beskese, and Kahraman 2007; Han, Lin, and } \\
\text { Chen 2008; Halim 2010; Suraj and Bontis 2012) }\end{array}$ & \\
\hline \multicolumn{3}{|c|}{ Interpersonal relationships } \\
\hline $\begin{array}{l}\text { Collaborative } \\
\text { capability }\end{array}$ & $\begin{array}{l}\text { "Collaboration capability consists of actor's capability to } \\
\text { build and manage network relationships based on mutual }\end{array}$ & \\
\hline
\end{tabular}




\begin{tabular}{|c|c|c|}
\hline & $\begin{array}{l}\text { trust, communication and commitment." (Blomqvist \& Levy } \\
2006, \text { p.41) }\end{array}$ & \multirow[b]{2}{*}{$\begin{array}{l}\text { Communication } \\
\text { and information } \\
\text { exchange }\end{array}$} \\
\hline & $\begin{array}{l}\text { (Cardinal, Alessandri, and Turner 2001; Bontis and Fitz-enz } \\
\text { 2002; Alwert, Bornemann, and Kivikas 2004; F. Tunc } \\
\text { Bozbura 2004; F. T. Bozbura, Beskese, and Kahraman 2007; } \\
\text { Han, Lin, and Chen 2008; Halim 2010; Suraj and Bontis 2012; } \\
\text { Z. Wang, Wang, and Liang 2014) }\end{array}$ & \\
\hline \multicolumn{3}{|c|}{ Skills and attitudes } \\
\hline \multirow[b]{2}{*}{$\begin{array}{l}\text { Education and } \\
\text { competency } \\
\text { development }\end{array}$} & $\begin{array}{l}\text { "Competency development is a capability of individual to } \\
\text { increase number and level of competencies to a required } \\
\text { level." (based on Draganidis \& Mentzas 2006) }\end{array}$ & \multirow[b]{2}{*}{$\begin{array}{l}\text { Competence and } \\
\text { knowledge } \\
\text { development }\end{array}$} \\
\hline & $\begin{array}{l}\text { (Johanson, Martensson, and Skoog 1999; Bontis and Fitz-enz } \\
\text { 2002; Alwert, Bornemann, and Kivikas 2004; F. Tunc } \\
\text { Bozbura 2004; J. Chen, Zhu, and Xie 2004; Hayton 2005; W.- } \\
\text { Y. Wang and Chang 2005; F. T. Bozbura, Beskese, and } \\
\text { Kahraman 2007; Sharabati, Jawad, and Bontis 2010; Suraj and } \\
\text { Bontis 2012; Z. Wang, Wang, and Liang 2014) }\end{array}$ & \\
\hline \multirow[b]{2}{*}{ Creativity } & $\begin{array}{l}\text { "Creativity is a constellation of personality and intellectual } \\
\text { traits shown by individual." (Amabile 1988, p.125) }\end{array}$ & \multirow{2}{*}{$\begin{array}{l}\text { Competence and } \\
\text { knowledge } \\
\text { development; } \\
\text { Innovativeness } \\
\text { and ideation } \\
\text { capability }\end{array}$} \\
\hline & $\begin{array}{l}\text { (Cardinal, Alessandri, and Turner 2001; F. Tunc Bozbura } \\
\text { 2004; J. Chen, Zhu, and Xie 2004; Han, Lin, and Chen 2008; } \\
\text { Sharabati, Jawad, and Bontis 2010; Z. Wang, Wang, and } \\
\text { Liang 2014) }\end{array}$ & \\
\hline \multirow[b]{2}{*}{ Expertise } & $\begin{array}{l}\text { "Expertise is a possession of superior skills or knowledge in a } \\
\text { particular area of study." (Herling 2000, p. 9) }\end{array}$ & \multirow[b]{2}{*}{$\begin{array}{l}\text { Competence and } \\
\text { knowledge } \\
\text { development }\end{array}$} \\
\hline & $\begin{array}{l}\text { (Bontis and Fitz-enz 2002; F. Tunc Bozbura 2004; J. Chen, } \\
\text { Zhu, and Xie 2004; Marr, Schiuma, and Neely 2004; } \\
\text { Leiponen 2005; Hayton 2005; F. T. Bozbura, Beskese, and } \\
\text { Kahraman 2007; Han, Lin, and Chen 2008; Halim 2010; } \\
\text { Sharabati, Jawad, and Bontis 2010; Suraj and Bontis 2012; Z. } \\
\text { Wang, Wang, and Liang 2014) }\end{array}$ & \\
\hline \multicolumn{3}{|c|}{ Individual and team agility } \\
\hline \multirow{2}{*}{ Flexibility } & $\begin{array}{l}\text { "Flexibility is a capability to cope with new unexpected } \\
\text { situations and to recover from any difficulties in the } \\
\text { workplace." (Varlander 2012) }\end{array}$ & \multirow{2}{*}{$\begin{array}{l}\text { Competence and } \\
\text { knowledge } \\
\text { development; } \\
\text { Communication } \\
\text { and information } \\
\text { exchange }\end{array}$} \\
\hline & (Wojtczuk-Turek and Turek 2015) & \\
\hline \multirow{2}{*}{$\begin{array}{l}\text { Learning } \\
\text { capability }\end{array}$} & $\begin{array}{l}\text { "Learning capability is the capacity to assimilate knowledge } \\
\text { (for imitation)." (Kim 1998, p. 507) }\end{array}$ & \multirow{2}{*}{$\begin{array}{l}\text { Competence and } \\
\text { knowledge } \\
\text { development }\end{array}$} \\
\hline & $\begin{array}{l}\text { (Cardinal, Alessandri, and Turner 2001; J. Chen, Zhu, and Xie } \\
\text { 2004; W.-Y. Wang and Chang 2005) }\end{array}$ & \\
\hline \multicolumn{3}{|c|}{ Structural capital } \\
\hline \multirow[b]{2}{*}{$\begin{array}{l}\mathrm{R} \& \mathrm{D} \\
\text { (Innovative) } \\
\text { activities }\end{array}$} & $\begin{array}{l}\text { R\&D activities are defined as systematic and planned creative } \\
\text { work whose purpose is increasing individual and } \\
\text { organizational stock of knowledge (OECD 2002). }\end{array}$ & \multirow[b]{2}{*}{$\begin{array}{l}\text { Innovativeness } \\
\text { and ideation } \\
\text { capability }\end{array}$} \\
\hline & $\begin{array}{l}\text { (Cardinal, Alessandri, and Turner 2001; Alwert, Bornemann, } \\
\text { and Kivikas 2004; F. Tunc Bozbura 2004; J. Chen, Zhu, and } \\
\text { Xie 2004; Hayton 2005; Halim 2010; Sharabati, Jawad, and } \\
\text { Bontis 2010; Suraj and Bontis 2012; Z. Wang, Wang, and } \\
\text { Liang 2014) }\end{array}$ & \\
\hline \multirow{2}{*}{$\begin{array}{l}\text { Organizational } \\
\text { culture }\end{array}$} & $\begin{array}{l}\text { "Organizational culture is defined as a set of commonly-held } \\
\text { values, beliefs and assumptions within an organization which } \\
\text { influences employees' perceptions and behaviour." (Ke \& Wei } \\
2008, \text { p. 211) }\end{array}$ & \multirow{2}{*}{$\begin{array}{l}\text { Communication } \\
\text { and information } \\
\text { exchange }\end{array}$} \\
\hline & $\begin{array}{l}\text { (Nonaka and Takeuchi 1995; Brooking 1997; Johanson, } \\
\text { Martensson, and Skoog 1999; Bontis and Fitz-enz 2002; } \\
\text { Alwert, Bornemann, and Kivikas 2004; F. Tunc Bozbura }\end{array}$ & \\
\hline
\end{tabular}




\begin{tabular}{|c|c|c|}
\hline & $\begin{array}{l}\text { 2004; J. Chen, Zhu, and Xie 2004; Carmeli and Tishler 2004; } \\
\text { W.-Y. Wang and Chang 2005; Halim 2010; Sharabati, Jawad, } \\
\text { and Bontis 2010; Suraj and Bontis 2012; Z. Wang, Wang, and } \\
\text { Liang 2014) }\end{array}$ & \\
\hline \multirow[t]{2}{*}{$\begin{array}{l}\text { Organizational } \\
\text { structure }\end{array}$} & $\begin{array}{l}\text { "Organizational structure includes the nature of } \\
\text { formalization, layers of hierarchy, level of horizontal } \\
\text { integration, centralization of authority (locus of decision- } \\
\text { making), and patterns of communication." (Nahm et al. 2003, } \\
\text { p. } 283 \text { ) }\end{array}$ & \multirow[t]{2}{*}{$\begin{array}{l}\text { Communication } \\
\text { and information } \\
\text { exchange }\end{array}$} \\
\hline & $\begin{array}{l}\text { (Cardinal, Alessandri, and Turner 2001; J. Chen, Zhu, and Xie } \\
\text { 2004; Marr, Schiuma, and Neely 2004; Hayton 2005) }\end{array}$ & \\
\hline \multirow{2}{*}{$\begin{array}{l}\text { Organizational } \\
\text { learning }\end{array}$} & $\begin{array}{l}\text { "Organizational learning is a process through which workers } \\
\text { learn gradually in the work context through experience, } \\
\text { reflection on work practice and collaboration with } \\
\text { colleagues." (Mulholland et al. 2001, p. } 337 \text { ) }\end{array}$ & \multirow{2}{*}{$\begin{array}{l}\text { Competence and } \\
\text { knowledge } \\
\text { development; } \\
\text { Communication } \\
\text { and information } \\
\text { exchange }\end{array}$} \\
\hline & $\begin{array}{l}\text { (Nonaka and Takeuchi 1995; Cardinal, Alessandri, and Turner } \\
\text { 2001; Alwert, Bornemann, and Kivikas 2004; J. Chen, Zhu, } \\
\text { and Xie 2004; Gallego and Rodríguez 2005; Halim 2010; I. } \\
\text { Hsu and Sabherwal 2012; Suraj and Bontis 2012; Z. Wang, } \\
\text { Wang, and Liang 2014) }\end{array}$ & \\
\hline
\end{tabular}

\subsubsection{Refinement Phase 3}

In this phase face validation of the 70 candidate indicators was carried out using experts from two companies. One company was a SME, while the other was a large enterprise, however, both worked with complex engineering design projects. This profile of experts was selected because these company types form the main target for large-scale performance measurement systems, and aligned with prior studies of e.g. Rolls Royce (Haque and James-Moore 2004). In order to check initial generalisability the selected companies were from the automotive and energy sectors.

Prior to these workshops, introduction meetings were held in both companies to clarify the context and define the aims and procedure. Workshop participants represented HR, quality assurance, product and production development, and management. In addition, a performance measurement consultant was also involved in one of the workshops to provide an additional perspective. The background of the experts is summarised in Table 2.

Table 2: Background of experts used in indicator refinement

\begin{tabular}{|c|c|c|}
\hline \multirow{2}{*}{ Sector } & \multicolumn{2}{|c|}{ Expert breakdown } \\
\hline & Field of expertise & Number of participants \\
\hline \multirow{4}{*}{ Automotive } & IT & 1 \\
\hline & Logistics & 2 \\
\hline & Management & 1 \\
\hline & Development & 8 \\
\hline
\end{tabular}




\begin{tabular}{|c|l|l|}
\hline & Engineering sales \& procurement & 6 \\
\hline \multirow{3}{*}{ Energy } & Management & 2 \\
\cline { 2 - 3 } & Quality & 1 \\
\cline { 2 - 3 } & Development & 15 \\
\hline Independent & Performance measurement consultant & 1 \\
\hline \multicolumn{2}{|l|}{ Overall } & 37 \\
\hline
\end{tabular}

During each workshop perceived level of indicator overlap, importance (alignment with corporate strategy), and practical understanding (intuitiveness in an operational context) were assessed. The importance level was used to assess the indicators at the individual and team levels with respect to each company's strategy and working practice. Here, despite differences between the companies, almost all indicators were rated as relevant in the context of the complex projects and design work undertaken. However, five items were removed at this phase due to their redundancy in practical application. This was based on explicit assessment of overlap using the definition of each indicator (e.g. two indicators related to sharing knowledge and helping others within the team were considered to be practically indistinguishable by managers). Finally, the level of understanding and importance assessment was used to refine the communication and operationalization of indicators that were not intuitive or logical from a practical perspective (e.g. potential indicator "New ideas suggested during team activities related to the product context" into "Number of ideation sessions during team activities regarding product"). This resulted in a final list of 65 indicators with associated operationalized measures.

\subsubsection{Operationalization of Indicators}

The final set of 65 indicators is listed in Table 3 for the individual level (36 indicators) and Table 4 for the team level (29 indicators). These tables also include all the operational information required for implementation (Tables 3 and 4 - columns "Data collection" and "Implementation"). These indicators translate the measureless and nonoperationalized variables associated with the various measurement areas described in Table 1, into fully operationalized and applicable measures. The practice based aspect of this refinement and initial validation process is detailed below.

Table 3: Operationalized performance indicators at the individual level

\begin{tabular}{|l|l|l|}
\hline \multicolumn{3}{|c|}{ Individual level } \\
\hline Competences and knowledge & Data collection & Implementation \\
\hline \hline
\end{tabular}




\begin{tabular}{|c|c|c|c|}
\hline "CK_IN1 & Problem solving & survey & " average grade - 360 performance assessment \\
\hline CK_IN2 & Decision making & survey & average grade - 360 performance assessment \\
\hline CK_IN3 & Fast and detailed feedback & survey & average grade - 360 performance assessment \\
\hline CK_IN4 & $\begin{array}{l}\text { Define and understand roles and } \\
\text { responsibilities }\end{array}$ & survey & average grade -360 performance assessment \\
\hline CK_IN5 & Monitor and evaluate team performance & survey & average grade -360 performance assessment \\
\hline CK_IN6 & Leadership & survey & average grade -360 performance assessment \\
\hline CK_IN7 & $\begin{array}{l}\text { General IT literacy (OS, Office tools, } \\
\text { Internet) }\end{array}$ & survey & average grade -360 performance assessment \\
\hline CK_IN8 & $\begin{array}{l}\text { Specific IT literacy (Function specific } \\
\text { software) }\end{array}$ & survey & average grade - 360 performance assessment \\
\hline CK_IN9 & $\begin{array}{l}\text { Relevance of individual competences to } \\
\text { task description }\end{array}$ & survey & average grade - 360 performance assessment \\
\hline CK_IN10 & Technical knowledge & survey & average grade -360 performance assessment \\
\hline CK_IN11 & Creative ability & survey & average grade - 360 performance assessment \\
\hline CK_IN12 & Social skills & survey & average grade - 360 performance assessment \\
\hline CK_IN13 & Responsibility & survey & average grade - 360 performance assessment \\
\hline CK_IN14 & Learning ability & survey & average grade - 360 performance assessment \\
\hline CK_IN15 & $\begin{array}{l}\text { Competence development expense/team } \\
\text { member }\end{array}$ & $\begin{array}{l}\text { IT system } \\
\text { integration }\end{array}$ & costs of team member education \\
\hline \multicolumn{2}{|c|}{ Communication and information sharing } & Data collection & Implementation \\
\hline CI_IN1 & $\begin{array}{l}\text { Number of best practices contributed, } \\
\text { per team member }\end{array}$ & $\begin{array}{l}\text { IT system } \\
\text { integration }\end{array}$ & number of practices from IT system \\
\hline CI_IN2 & $\begin{array}{l}\text { Number of solutions contributed, per } \\
\text { team member }\end{array}$ & $\begin{array}{l}\text { IT system } \\
\text { integration }\end{array}$ & number of solutions from IT system \\
\hline CI_IN3 & Participation in discussions & work sampling & percentage of time spent on discussions \\
\hline CI_IN4 & Participation in team meetings & work sampling & percentage of time spent on team meetings \\
\hline CI_IN5 & Participation in management meetings & work sampling & $\begin{array}{l}\text { percentage of time spent on management } \\
\text { meetings }\end{array}$ \\
\hline CI_IN6 & $\begin{array}{l}\text { Information received per week (face-to- } \\
\text { face/phone/email) }\end{array}$ & work sampling & $\begin{array}{l}\text { percentage of time when employee received } \\
\text { information }\end{array}$ \\
\hline CI_IN7 & $\%$ of recieved high quality information & work sampling & $\begin{array}{l}\text { percentage of time employee received } \\
\text { information assessed with higher quality }\end{array}$ \\
\hline CI_IN8 & $\begin{array}{l}\% \text { of information received directly from } \\
\text { colleague or via some other channel }\end{array}$ & work sampling & $\begin{array}{l}\text { percentage of time when employee received } \\
\text { information*percentage of used source }\end{array}$ \\
\hline CI_IN9 & $\begin{array}{l}\text { Information sent per week (face-to- } \\
\text { face/phone/email) }\end{array}$ & work sampling & $\begin{array}{l}\text { percentage of time when employee sent } \\
\text { information }\end{array}$ \\
\hline CI_IN10 & $\%$ of sent high quality information & work sampling & $\begin{array}{l}\text { percentage of time employee sent information } \\
\text { which was assessed with higher quality }\end{array}$ \\
\hline CI_IN11 & $\begin{array}{l}\% \text { of sent information directly to } \\
\text { colleague or via some other channel }\end{array}$ & work sampling & $\begin{array}{l}\text { percentage of time when employee sent } \\
\text { information*percentage of used source }\end{array}$ \\
\hline CI_IN12 & Participation in information exchange & work sampling & $\begin{array}{l}\text { percentage of time where employees } \\
\text { exchanged information }\end{array}$ \\
\hline CI_IN13 & $\begin{array}{l}\% \text { of exchanged high quality } \\
\text { information }\end{array}$ & work sampling & $\begin{array}{l}\text { percentage of time employees exchange } \\
\text { information assessed with higher quality }\end{array}$ \\
\hline CI_IN14 & $\begin{array}{l}\text { MB transfer (download, upload) per } \\
\text { employee }\end{array}$ & $\begin{array}{l}\text { IT system } \\
\text { integration }\end{array}$ & MB transfer from IT system \\
\hline
\end{tabular}




\begin{tabular}{|l|l|c|l|}
\hline CI_IN15 & Internships, Trainings, Development & $\begin{array}{c}\text { IT system } \\
\text { integration }\end{array}$ & $\begin{array}{l}\text { percentage of time spent on training, } \\
\text { internships etc. }\end{array}$ \\
\hline \hline \multicolumn{2}{|c|}{ Motivation and satisfaction } & Data collection & Implementation \\
\hline \hline MS_IN1 & Personal motivation & work sampling & $\begin{array}{l}\text { average grade obtained for each team member } \\
\text { within the day (scale 1-5) }\end{array}$ \\
\hline MS_IN2 & Personal satisfaction & survey & average grade of personal satisfaction \\
\hline \hline \multicolumn{2}{|c|}{ Innovativeness and ideation } & Data collection & Implementation \\
\hline II_IN1 & $\begin{array}{l}\text { Number of ideation activities regarding } \\
\text { product and process context }\end{array}$ & work sampling & self-explanatory \\
\hline II_IN3 & $\begin{array}{l}\text { \% of relevant ideation activities } \\
\text { regarding product and process contexts } \\
\text { other domains }\end{array}$ & work sampling & self-explanatory \\
\hline II_IN4 & $\begin{array}{l}\% \text { of relevant ideation activities } \\
\text { regarding other domains }\end{array}$ & work sampling & self-explanatory \\
\hline
\end{tabular}

Table 4: Operationalized performance measures at the team level

\begin{tabular}{|c|c|c|c|}
\hline \multicolumn{4}{|c|}{ Team level } \\
\hline & Competences and knowledge & $\begin{array}{c}\text { Data } \\
\text { collection }\end{array}$ & Implementation \\
\hline $\begin{array}{l}\text { CK_TM1 } \\
\end{array}$ & $\begin{array}{l}\text { Number of team members with insufficient } \\
\text { competencies }\end{array}$ & survey & $\begin{array}{l}\text { based on average grades from } 360 \\
\text { performance assessment (team members with } \\
\text { low average grade) }\end{array}$ \\
\hline CK_TM2 & Number of outstanding team members & survey & $\begin{array}{l}\text { based on average grades from } 360 \\
\text { performance assessment (team members with } \\
\text { high average grade) }\end{array}$ \\
\hline CK_TM3 & Number of competencies with low grades & survey & $\begin{array}{l}\text { based on answers from } 360 \text { assessment } \\
\text { method (competencies with low average } \\
\text { grade) }\end{array}$ \\
\hline CK_TM4 & Number of isolated team members & $\begin{array}{c}\text { work } \\
\text { sampling }\end{array}$ & $\begin{array}{l}\text { based on information about interactions within } \\
\text { the team }\end{array}$ \\
\hline$\overline{\text { CK_TM5 }}$ & $\begin{array}{l}\text { Number of non-human resources which are } \\
\text { not used }\end{array}$ & $\begin{array}{c}\text { work } \\
\text { sampling }\end{array}$ & $\begin{array}{l}\text { based on information on used resources } \\
\text { (number of resources which are rarely used) }\end{array}$ \\
\hline \multicolumn{2}{|c|}{ Communication and information sharing } & $\begin{array}{c}\text { Data } \\
\text { collection }\end{array}$ & Implementation \\
\hline CI_TM1 & $\begin{array}{l}\text { To what extent team members re-use } \\
\text { knowledge (solutions/contributions) from } \\
\text { internal sources }\end{array}$ & survey & $\begin{array}{l}\text { based on average rating (scale } 1-5 \text { ) made by } \\
\text { team members }\end{array}$ \\
\hline CI_TM2 & $\begin{array}{l}\text { To what extent team members re-use } \\
\text { knowledge (solutions/contributions) from } \\
\text { external sources }\end{array}$ & survey & $\begin{array}{l}\text { based on average rating (scale 1-5) for the } \\
\text { whole team }\end{array}$ \\
\hline CI_TM3 & $\begin{array}{l}\text { To what extent is knowledge captured in } \\
\text { internal databases }\end{array}$ & survey & $\begin{array}{l}\text { based on average rating (scale 1-5) for the } \\
\text { whole team }\end{array}$ \\
\hline CI_TM4 & $\begin{array}{l}\text { To what extent team members feel } \\
\text { comfortable reusing solutions/contributions }\end{array}$ & survey & $\begin{array}{l}\text { based on average rating (scale 1-5) for the } \\
\text { whole team (Orr and Persson 2003) }\end{array}$ \\
\hline
\end{tabular}




\begin{tabular}{|c|c|c|c|}
\hline CI_TM5 & $\begin{array}{l}\text { To what extent team members feel motivated } \\
\text { sharing their knowledge }\end{array}$ & survey & $\begin{array}{l}\text { based on average rating (scale } 1-5 \text { ) for the } \\
\text { whole team }\end{array}$ \\
\hline CI_TM6 & $\begin{array}{l}\text { To what extent team members consider that } \\
\text { team activities generate more experience and } \\
\text { contributions for an individual }\end{array}$ & survey & $\begin{array}{l}\text { based on average rating (scale 1-5) for the } \\
\text { whole team }\end{array}$ \\
\hline CI_TM7 & $\begin{array}{l}\text { To what extent team members feel } \\
\text { comfortable sharing their knowledge }\end{array}$ & survey & $\begin{array}{l}\text { based on average rating (scale 1-5) for the } \\
\text { whole team (Orr and Persson 2003) }\end{array}$ \\
\hline CI_TM8 & $\begin{array}{l}\text { To what extent team members can easily } \\
\text { find team members with the needed } \\
\text { competencies }\end{array}$ & survey & $\begin{array}{l}\text { based on average rating (scale 1-5) for the } \\
\text { whole team }\end{array}$ \\
\hline CI_TM9 & $\begin{array}{l}\text { To what extent team members consider the } \\
\text { databases to be user friendly }\end{array}$ & survey & $\begin{array}{l}\text { based on average rating (scale 1-5) for the } \\
\text { whole team (Orr and Persson 2003) }\end{array}$ \\
\hline CI_TM10 & $\begin{array}{l}\text { To what extent team members feel they have } \\
\text { been provided with sufficient information } \\
\text { about new inputs and solutions }\end{array}$ & survey & $\begin{array}{l}\text { based on average rating (scale 1-5) for the } \\
\text { whole team }\end{array}$ \\
\hline CI_TM11 & Number of weak communication links & $\begin{array}{c}\text { work } \\
\text { sampling }\end{array}$ & $\begin{array}{l}\text { based on information about interaction } \\
\text { between two members (number of Simmelian } \\
\text { ties (Krackhardt 1999)) }\end{array}$ \\
\hline CI_TM12 & Number of strong communication links & $\begin{array}{c}\text { work } \\
\text { sampling }\end{array}$ & $\begin{array}{l}\text { based on information about interaction } \\
\text { between two members (number of Simmelian } \\
\text { ties (Krackhardt 1999)) }\end{array}$ \\
\hline & Motivation and satisfaction & $\begin{array}{c}\text { Data } \\
\text { collection }\end{array}$ & Implementation \\
\hline MS_TM1 & Team member motivation & $\begin{array}{c}\text { work } \\
\text { sampling }\end{array}$ & $\begin{array}{l}\text { based on average rating (scale 1-5) for the } \\
\text { whole team }\end{array}$ \\
\hline MS_TM2 & Time spent on non-working social activities & $\begin{array}{l}\text { IT system } \\
\text { integration }\end{array}$ & $\begin{array}{l}\text { number of hours spent on teambuilding } \\
\text { activities }\end{array}$ \\
\hline MS_TM3 & $\%$ of activities done with lower motivation & $\begin{array}{c}\text { work } \\
\text { sampling }\end{array}$ & $\begin{array}{l}\text { based on information about individual } \\
\text { motivation during sampled activities }\end{array}$ \\
\hline MS_TM4 & $\%$ of irrelevant activities for their assignment & $\begin{array}{c}\text { work } \\
\text { sampling }\end{array}$ & self-explanatory \\
\hline & "Innovativeness and ideation & $\begin{array}{c}\text { Data } \\
\text { collection }\end{array}$ & Implementation \\
\hline II_TM1 & $\begin{array}{l}\text { To what extent is tolerated to think well } \\
\text { outside the box }\end{array}$ & survey & $\begin{array}{l}\text { based on average rating (scale 1-5) for the } \\
\text { whole team }\end{array}$ \\
\hline II_TM2 & $\begin{array}{l}\text { To what extent is culture of renewal } \\
\text { (overthrowing the existing) present in the } \\
\text { team }\end{array}$ & survey & $\begin{array}{l}\text { based on average rating (scale 1-5) for the } \\
\text { whole team }\end{array}$ \\
\hline II_TM3 & $\begin{array}{l}\text { To what extent is innovation an objective of } \\
\text { the manager }\end{array}$ & survey & $\begin{array}{l}\text { based on average rating (scale 1-5) for the } \\
\text { whole team }\end{array}$ \\
\hline II_TM4 & $\begin{array}{l}\text { To what extent is level of support (monetary, } \\
\text { time, encouragement, etc.) given by the } \\
\text { manager to innovation aspect of the project }\end{array}$ & survey & $\begin{array}{l}\text { based on average rating (scale 1-5) for the } \\
\text { whole team }\end{array}$ \\
\hline II_TM5 & $\begin{array}{l}\text { Number of ideation sessions during team } \\
\text { activities regarding product }\end{array}$ & $\begin{array}{c}\text { work } \\
\text { sampling }\end{array}$ & self-explanatory \\
\hline II_TM6 & $\begin{array}{l}\% \text { of relevant ideation sessions during team } \\
\text { activities regarding product }\end{array}$ & $\begin{array}{c}\text { work } \\
\text { sampling }\end{array}$ & self-explanatory \\
\hline
\end{tabular}




\begin{tabular}{|l|l|c|l|}
\hline II_TM7 & $\begin{array}{l}\text { Number of ideation sessions during team } \\
\text { activities reagarding other domains }\end{array}$ & $\begin{array}{c}\text { work } \\
\text { sampling }\end{array}$ & self-explanatory \\
\hline II_TM8 & $\begin{array}{l}\text { \% of relevant ideation sessions during team } \\
\text { activities reagarding other domains }\end{array}$ & $\begin{array}{c}\text { work } \\
\text { sampling }\end{array}$ & self-explanatory \\
\hline
\end{tabular}

Key to application of a cohesive measurement approach is integration between levels of analysis as illustrated in Figure 2. In order to provide this, three specific data collection strategies are proposed based on the theoretical requirements outlined in Section 2: work sampling, survey, and integration with corporate IT systems (Tables 3 and 4). Below we outline the basic technical characteristics of each approach.

Work sampling: Work sampling provides a large amount of multi-dimensional data based on a self-assessment protocol, which is suitable for automated statistical analysis, reduces respondent bias, and increases the immediacy of measurement (Robinson 2009). As such, it is a key differentiation from previous approaches. Further, Robinson (2010) has previously demonstrated this approach in the engineering design domain. Work sampling is ideal for data collection in the context of the approach outlined in Figure 2 due to its ability to dynamically trace fine-grain measures, and individual contribution to wider team work (Faure 2009). The number of questions that respondents had to answer differed based on the activity type they were conducting (e.g. for individual technical activities participants were asked to respond on 9 screens). The questions were related to the work context (solo-technical, solo-administrative, teamwork), product development activity type (based on Sim and Duffy (2003) ontology of activities), activity context (product - mechanical, electrical, software, process - maintenance, manufacturing etc.), party (organizational structure was imported in work sampling application beforehand), manner (face-to-face, email, teleconference etc.), motivation (on a scale 1 to 5) etc. Here, motivation was measured via Likert scales following the approach previously validated by Robinson (2009). A single-item measure was used because of the intensity of the data collection and to minimize time spent on data insertion (Fuchs and Diamantopoulos 2009). Overall, the percentage of time spent on a certain activity or within a specific context is calculated based on the ratio between time that participant spends conducting it and overall time spent on all activities (by the same participant). For more details on the mathematical 
description of work sampling in engineering design research, please consult Robinson (2009).

Survey: The 360-Degree performance assessment survey served to provide coarsegrain data tying the fine-grain work sampling based measures into the wider framework. 360-Degree performance assessment was conducted after sampling sessions and involved team members and team leaders. Team members were asked to evaluate the competencies of others based on the proposed list of indicators (CK_IN1 - CK_IN14). For the purposes of this work additional survey data was used to provide context for a particular team's e.g. information sharing experiences, knowledge reuse from internal and external sources etc.

IT Systems: Similarly, corporate IT systems provided higher-level indicators needed to align the multiple elements in the measurement framework (Figure 2), and can enable automatic extraction of collected data. Data for indicators listed in Tables 3 and 4 can be extracted partially from knowledge databases (CI_IN1 and CI_IN2) and HR databases (e.g. CK_IN15 and MS_TM2). From the knowledge databases, best practices and solutions can be extracted using a similar approach to Gopsill et al. (2014), focused on technical digital objects. In terms of HR databases, measurement was planned on a quarterly basis. For the purpose of this case, data was collected only once for the given period in order to demonstrate the application of these indicators.

\section{Example Case}

In this section the dynamic measurement approach is illustrated and critically evaluated with respect to its deployment in a real case. The purpose of this example case is to demonstrate the proposed approach in practice and to show how obtained results can facilitate understanding of individual and team work during engineering projects. It is important to note that full validation of the proposed approach is not possible via a single case study, and would require wide ranging quantitative evaluation after roll-out in practice. However, as each indicator is individually associated with performance as explained in Section 3, the proposed approach is theoretically robust. As such, this example case serves to illustrate how the approach can be applied in practice. 


\subsection{Case Context}

The case study described here was conducted in the SME introduced in Section 3, which was primarily concerned with the design of systems for generation, distribution, and transformation of electrical energy. Design and innovation had been identified as an important area of improvement in the company and thus new perspectives on how to measure performance in this context were being sought. As such, this provided a suitable environment for deployment of the approach, due to a high level of practical buy-in and theoretical relevance in terms of industrial sector and company size.

Within the specific development process in which the measurement approach was deployed, participants worked with a total of 13 projects in parallel. However, the two biggest projects took $31,6 \%$ and $29,5 \%$ of the total working time (based on work sampling data). In this context teams were project-based and multidisciplinary. Participants spent the majority of their time on product related activities associated with: electronics $(39,1 \%)$, software $(23,8 \%)$, and mechanics $(13,9 \%)$. Of the total participants, six predominantly worked with electronics, five with software, and four with mechanics. Finally, conceptualisation $(32,3 \%)$ and detailing $(26,7 \%)$ were found to be the major activities reported.

During data collection all indicators were used as outlined in Section 3.25. The work sampling period lasted for 10 work days, during which 1357 data points were recorded across a total of 15 participants working simultaneously on different engineering design projects (13 members of the technical team, a project manager, and the head of department). The work sampling was conducted using a self-reporting mobile application specifically developed as the part of the research and previously described in (Škec et al. 2015). The mobile application for work sampling has been designed as a sequence of input screens with predefined menus, following Robinson's approach (2010), and using the analogy with an electronic diary. The sampling period was preceded by training in the method and overall adaptation to the approach. All participants also completed the survey questionnaire described in Section 3.2.5, which was administered via email. Further, IT integration data was collected with the support of company representatives who provided all relevant data needed for the calculation of indicator values. This provided data on individual/team level activity and design process related performance when coupled with the coarse-grain measurements. 
Finally, all data was anonymised so that only the research team was able to identify specific participants by name. This ensured that participants were able to report data honestly and without fear of managerial oversight.

\subsection{Evaluation of the Dynamic Measurement Approach}

This section explores how the proposed approach worked in practice with respect to the key features outlined in Section 2: fine-grain, dynamic, and inclusion of intangibles.

\subsubsection{Fine-grain Measurement}

The results from the case illustrated how the fine-grain measures gave meaningful insight into the dynamic processes at the individual/team level in the case company. In particular the results show how the fine-grain measures gave a complementary perspective to the coarse-grain measures, and other project management processes employed in the company. This significantly extended the team leader's ability to follow dynamic responses to management decisions and to observe emerging project features.

An example of the value of fine-grain measurement is given in Figure 4.a. This shows the percentage of discussion type interactions (CI_IN3, Table 3) experienced by each participant. Here, it can be observed that some participants reported very little discussion and that the overall level of discussion was relatively low - sub 20\%; with only Team member 10 reporting everyday discussions. In addition, this dynamic representation was linked to the coarse-grain assessment of overall communication within the team. At this level several participants were singled out as being 'isolated' from the main team, with poor interaction throughout the sampling period (Figure 4.b). Specifically, indicators such as CI_IN3, CI_IN4, CI_IN5 provided insights about the type of team activities that were conducted, while indicators CI_IN6 and CI_IN9 supported the identification of "active" (those that give information e.g. team member 15) and "passive" (those that receive information e.g. team member 4) team members in terms of communication on a daily and weekly basis. Each of these indicators can be coupled with the activity context, helping to understand behaviour of certain team members related to a specific context. For example, Team member 15 gave information predominantly related to the software context ( $35 \%$ of information that he gave). Although these results were in line with the generally low level of communication 
expected at the later stages of project finalisation (see Section 4.1) they could also indicate the need for facilitating more information exchange. As such, the indicators conformed with theoretical expectations, the real-time insights of the team, and the coarse-grain lagging indicators. Thus, in conjunction with other measures this feature of dynamic information exchange could allow the team leader to identify and tackle problematic information exchange within the team before it could be identified using traditional approaches.

Further exploring this information exchange data using Simmelian ties (Krackhardt 1999), weak (CI_TM11) and strong communication (CI_TM12) links between team members could be identified. Using dynamic data to build a communication network, it was possible to identify isolated members as well as key communication hubs in realtime. In the presented case, team members 8 and 15 were recognized as key communication hubs. Again, this information conformed with feedback from the team itself and could be used by the team leader to direct communication support efforts. As such, the indicators provided substantial of additional insights that allowed for a more nuanced perspective on the management of communication within the team. This illustrates the value of fine-grain measures at this level where trends are apparent substantially before their impact would be detected in traditional coarse-grain performance measurement approaches.

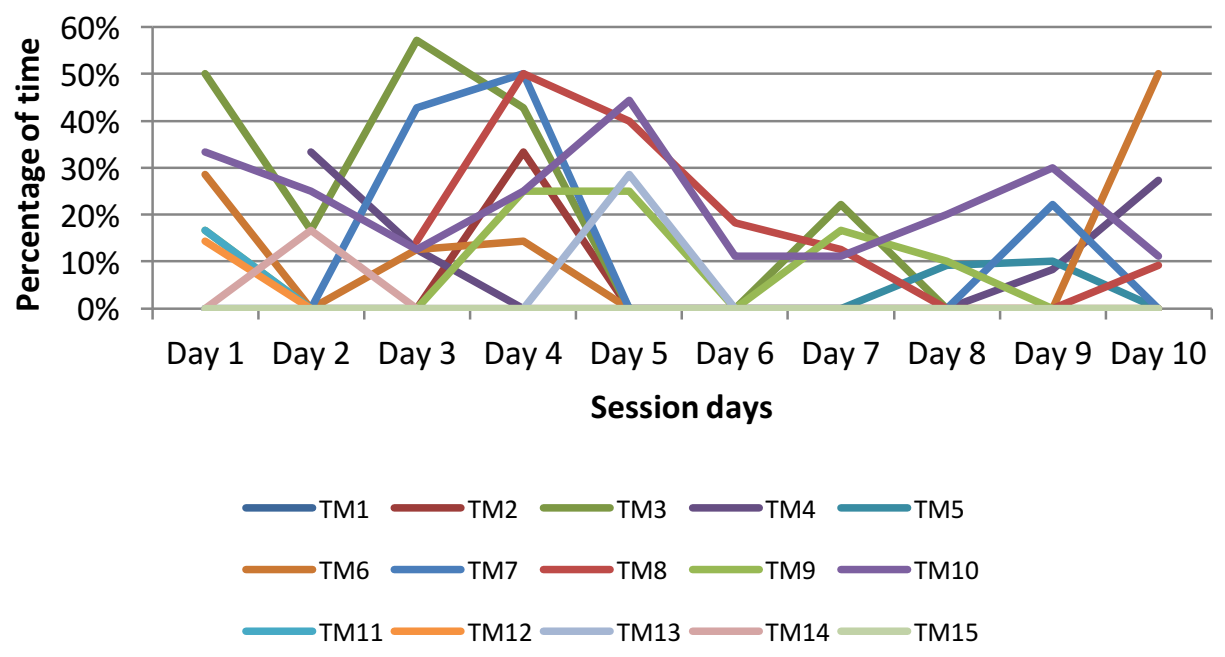




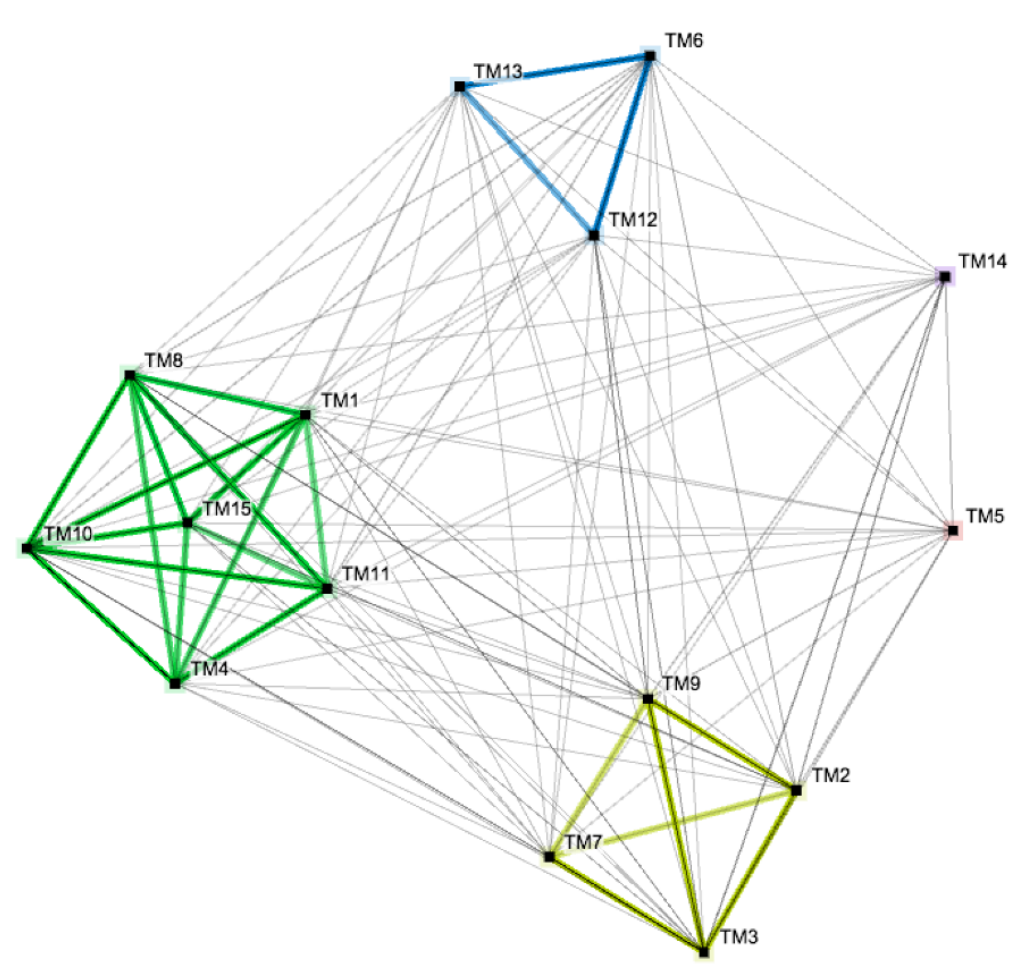

b)

Figure 4: Fine-grain measures of discussion type activities versus the coarse grain assessment of communication. a) fine-grain representation of discussion for each team member (1-15) b) coarse-grain identification of overall communication network for all team members

\subsubsection{Dynamic Measurement}

Building on the fine-grain data allowed for dynamic measurement of the project, providing real-time analysis and feedback on processes within the team. An example of such an analysis is given in Figure 5, which shows average motivation scores for each team member (see Section 3.2.5 for details of how this indicator was measured). This motivation indicator (MS_IN1) was subsequently linked to design activity and context type in order to trace the dynamic interaction between motivation level and the other indicators. Hence, by monitoring personal motivation in real time the team leader was better able to target team member's activities and assign resources for best performance within the context of the design project. For example, assigning detailing activities to Team member 10 because of their higher motivation level during that activity type. Overall, team members reported lower motivation levels while 
conducting administrative activities, but for some participants it is even possible to identify differences in motivation level during technical activities. For example, Team members 2 and 7 reported higher levels of motivation $(\mathrm{M}=3,60$ and $\mathrm{M}=4,33)$ for analysis activities in comparison to user support activities (both $\mathrm{M}=2,00$ ). Team member 4 assessed his motivation level high for decision making and evaluation activities (both $\mathrm{M}=4,00)$, in comparison to planning activities $(\mathrm{M}=2,00)$. In practice this allowed the team to identify and address motivation issues between team members both within and across projects, and directly observe the results of changes in the assigned activities.

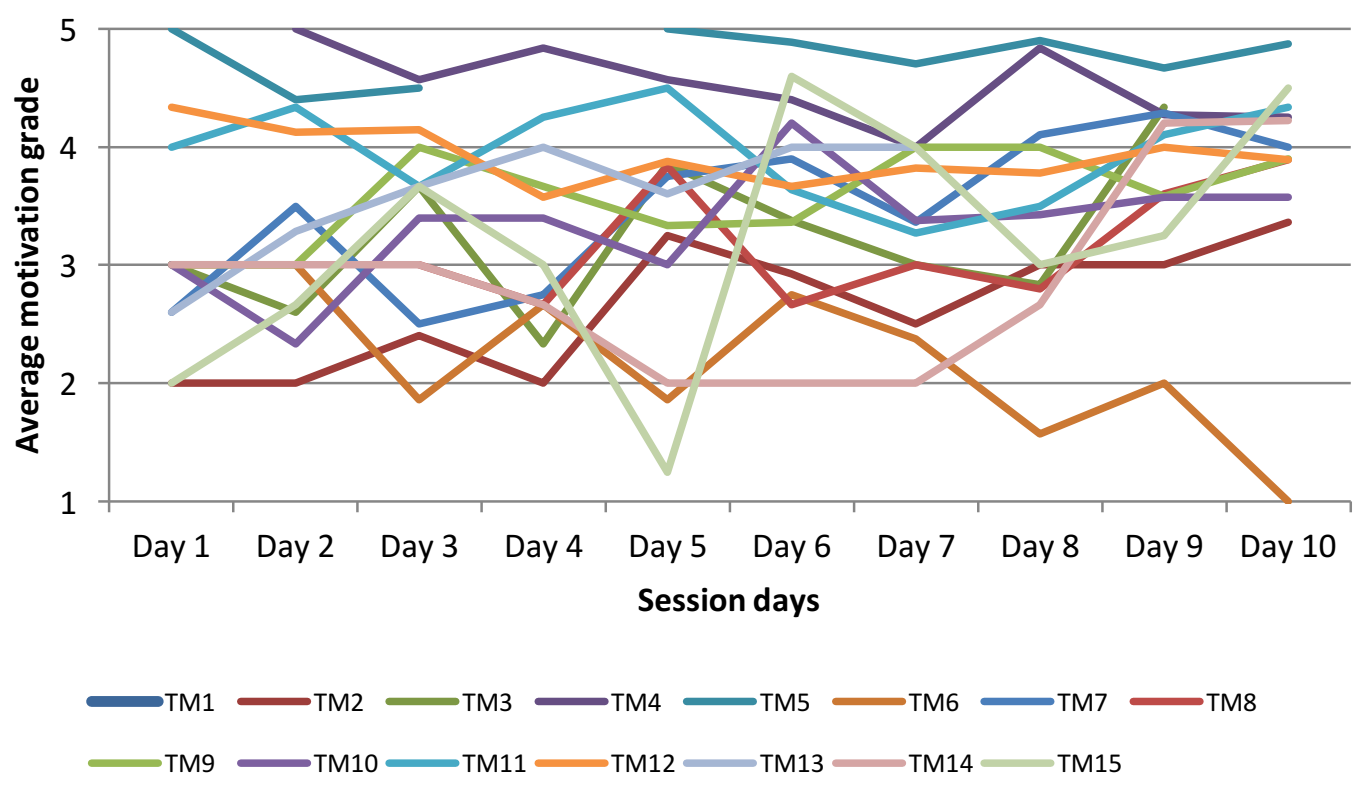

Figure 5: Dynamics of personal motivation level (MS_IN1) for each team member

Continuing the motivation example, the results showed that motivation level during team activities (MS_TM1) was lower than during individual activities (MS_IN1). This strongly confirmed the team's own self-evaluation and was explained as resulting from individuals' weak social skills (CK_IN12), as well as the frequency with which unmet goals were reported during team discussions. Further, the lower value of indicator CI_TM5 (related to knowledge sharing) also corroborated this explanation of difficulties stemming from poor communication. As such, these results conformed with the expectations of the team, and were distinctly aligned with the tasks they were working on. 
Although, many of the measures showed day-to-day variation wider trends were also observable at the week level. As such, the proposed approach provides valuable insight and feedback even with respect to rapid management approaches such as SCRUM (Moe, Dingsøyr, and Dybå 2010). This further illustrates the utility of deploying such a dynamic approach together with more static approaches where measures are taken at monthly or large increments. A key feature of the case was the utility of the results for managing the design team whilst using the coarse-grain measures of e.g. financial performance, for overall guidance. This supports the inclusion of such measurement elements in wider approaches, as proposed in Figure 2. Further, this highlights the complementarity of approaches such as that of Taylor (2016), who suggests indicators that are tangible and include aspects such as the number of agreements reached, frequency of communication problems, and availability of documents.

\subsubsection{Inclusion of Intangibles}

The final area of consideration was how the proposed approach integrated intangible measures in the wider performance measurement framework extant in the case company. In the case company it was typical for managers to track project progress with respect to tangible measures e.g. Gantt charts, but with limited insight into the day-to-day processes contributing to deviation from this plan. For example, project managers previously monitored Communication and information sharing based on the planned overlap in projects across team members, coupled with their "gut feeling" about individuals' social skills. This viewpoint only provides a coarse representation of team member interaction and is limited to the perspective of the project manager. In comparison to this, the proposed measures provided a real time picture of actual team member information behaviour. For example, Team member 7 reported less than $15 \%$ of team activities during sampling period. Further, they didn't report any "giving information" activities, suggesting their passivity in terms of information sharing. This was also supported by lower ratings in terms of Social Skills (CK_IN12). In contrast, it was possible to identify Team member 8 as a key hub of knowledge within the team due to the large amount of giving information. A similar integration example, was found when contrasting the company's yearly motivation surveys on the organizational level, and the dynamic data on team member motivation during the sampling period. 
As such, the presented fine-grain measures integrated with the company's traditional tangible framework to provide additional insights.

\subsection{Qualitative Evaluation by the Case Company}

Concluding the example case, follow-up discussions were held with the design team to assess applicability and real world relevance of the results. Here, team members confirmed that the proposed approach pointed to valid characteristics of their work and allowed them to more effectively monitor and quantify individual performance in real time. For example, the results highlighted key issues in terms of team collaboration and provided the team leader with deeper insights into everyday activities and information exchanges between team members. As such, the results from the proposed approach both aligned with theoretical and practical expectations given the project context (Section 4.1), and with the team's own self evaluation of the examined period. In particular, the results highlighted in this section were recognised by the team members and managers and were perceived as providing meaningful feedback on performance within the case company.

\section{Comparison with Extant Approaches and Discussion}

One means of evaluating the proposed approach is to contrast it with alternative current approaches based on the case data. One such approach is the Organisational Risk Analyser (ORA) (Carley and Reminga 2004). The ORA gives insight into overall organizational performance and risks associated with critical team members, competencies, resources, and activities. Thus, results of the proposed approach can be compared with insights derived from ORA in terms of their coverage of intangible aspects (Carley and Reminga 2004). However, due to the scope of ORA comparison is only possible in the competence and knowledge development and communication and information exchange areas. This comparison is to be expected due to the general limitations of current approaches outlined in Section 2. However, the commonality between the theoretical foundations of ORA and the proposed approach do give grounds for comparison within the two highlighted areas.

The comparison with ORA revealed a broad alignment between the approaches, as described in Table 5. For example, both approaches identified the same key team 
members, competencies, and areas for improvement. Further, there was agreement on the critical knowledge elements and communication indicators. Overall, the comparable elements of the proposed approach coincide with the results derived from ORA, despite the method for their evaluation being radically different. The alignment between these significantly different mathematical interpretations of the dataset supports the validity of the proposed approach, in addition to the qualitative validation given by the case evaluation (Section 4.3).

Table 5: Comparison of results obtained using existing and proposed approaches

\begin{tabular}{|c|c|}
\hline Results - using ORA approach & Results - proposed approach \\
\hline \multicolumn{2}{|c|}{ Competence and knowledge development } \\
\hline $\begin{array}{l}\text { Identification of strong competencies (General } \\
\text { IT literacy, Problem solving, Technical } \\
\text { knowledge) } \\
\text { Identification of weak competencies (Decision } \\
\text { making, Social Skills, Creative ability) } \\
\text { Identification of the most and the least } \\
\text { competent team members }\end{array}$ & $\begin{array}{l}\text { Identification of strong competencies (General } \\
\text { IT literacy, Problem solving, Technical } \\
\text { knowledge) } \\
\text { Identification of weak competencies (Decision } \\
\text { making, Social Skills, Creative ability) } \\
\text { Identification of the most and the least } \\
\text { competent team members } \\
\text { Complementary: } \\
\text { Analysis of competence level distributions } \\
\text { among team members for each specific } \\
\text { competence }\end{array}$ \\
\hline \multicolumn{2}{|c|}{ Communication and information exchange } \\
\hline $\begin{array}{l}\text { Identification of team members that have } \\
\text { central communication role within the team } \\
\text { (TM 10, TM 15, TM 8) } \\
\text { Identification of team members that are isolated } \\
\text { from the team (TM 11, TM 3, TM 14) }\end{array}$ & $\begin{array}{l}\text { Identification of team members that have central } \\
\text { communication role within the team (TM 10, } \\
\text { TM 15, TM 8) } \\
\text { Identification of team members that are isolated } \\
\text { from the team (TM 11, TM 3, TM 14) } \\
\text { Complementary: Analysis of daily dynamics } \\
\text { of information exchange for each team member } \\
\text { and for team as a whole in terms of: } \\
\text { - Direction of information exchange } \\
\text { (one-directional, bi-directional) } \\
\text { Manner of information exchange (e.g. } \\
\text { face-to-face) } \\
\text { Context of information exchange } \\
\text { (product or process) } \\
\text { Frequency of information exchange } \\
\text { (daily, weekly) }\end{array}$ \\
\hline
\end{tabular}

In terms of competencies and knowledge the approach allows for integration of coarse and fine-grain data by connecting e.g. the 360-Degree performance assessment type data to manifest assessment of dynamic activity. This provides a richer insight into how competencies influence individual/team work (Zika-Viktorsson and Ritzén 2005), as well as how these can be managed within a dynamic project. In particular this extends 
prior frameworks where competencies are typically treated as independent constructs and thus disconnected from the day to day activity and gradual development of the designer, as highlighted by (Matsumoto et al. 2005). In this way, the proposed framework supports longer term understanding of how various task-oriented and people-oriented competencies are relevant in everyday activities.

In terms of communication and information sharing three previous measurement approaches can be identified (Adams, Bessant, and Phelps 2006): the first measures the linkages between the development group and external sources; the second measures information gathering processes conducted internally; and the third measures customer contacts. The proposed approach integrates these previously disparate measures to provide real time insight into information exchange internally and externally. Further, this multifaceted assessment gives a rich description of information flows, facilitating interpretation. In current approaches, communication is measured by various integration mechanisms. For example committees, meetings, contacts (Damanpour 1991) at the high level, or protocol data at the low level (Stempfle and Badke-Schaub 2002), while assessment of external communications tends to focus on whether communication is taking place, the level at which it occurs, and with whom (Adams, Bessant, and Phelps 2006). In contrast, approaches based on the analysis of digital engineering objects (e.g. Gopsill et al. 2016) or emails (Wasiak et al. 2011) are focused on monitoring digital traces of engineering work. The proposed approach bridges these elements and enables monitoring of the associated information activities, key to successful design projects (Aurisicchio, Bracewell, and Wallace 2009). This gives new insight into how people give, receive (unidirectional), exchange (bidirectional) or process information, as well as how information flows are directly related to engineering design work. In addition, by coupling communication and information sharing indicator values with data management systems (PLM, CAD) and knowledge databases, new opportunities arise for analysing how information is retrieved and requested by engineers (Aurisicchio, Bracewell, and Wallace 2013).

In terms of creativity and innovation there has been considerable work on the situational and psychological factors conducive to design. Prior approaches in this domain include the Team Climate Inventory (TCI) (Anderson and West, 1998; Anderson and West, 1996) and the KEYS instrument for assessing the work environment for creativity 
(Amabile et al. 1996). Here, the proposed approach provides a complementary perspective allowing creativity assessments to be linked to design activity and individual/team performance. Further, the proposed approach allows teams to be dynamically tailored to the design task at hand by providing insight into communication and team interactions. These can then be contrasted with generic characteristics of design teams such as those provided by Ernst (2002) (e.g. multidisciplinary, interfunctional communication, and level of co-operation). All these features can be inferred from the proposed indicators and their direct effect on engineering design process performance monitored and controlled in real time rather than set out a priori.

In terms of motivation and satisfaction, the approach connects these elements to real world process dynamics. For example, motivation values are linked to actual design activities. As such, prior research in this area is extended via the fine grain measures related to design activity compared to coarse grain measures derived from surveys. The proposed approach can thus be used to identify and analyse both patterns of design behaviour, and their antecedents and outcomes in terms of motivation. Deeper analysis of motivation and satisfaction values could then be used to elucidate type, duration, and intensity of designer behaviour during different phases of engineering design (Dwivedula, Bredillet, and Müller 2012). For example, this can provide insight into how work overload and pressure affect designers behaviour (Van Yperen, Wörtler, and De Jonge 2016).

Thus, the proposed approach addresses the major of internal drivers of team performance identified by MacBryde and Mendibil (2003) such as skills, knowledge, communication, collaboration, innovation etc. and provides operationalized means for their monitoring and measurement. Further, considering the issues highlighted in Section 2: heterogeneous application and data landscapes, performance indicator inflation, and pseudo-accuracy. The proposed approach addresses data heterogeneity by building on a consistent and cohesive measurement framework. Indicator inflation and pseudo-accuracy are addressed by directly monitoring indicators in context, in a manner complementary to traditional lagging indicators, ensuring alignment with organisation strategy. 


\subsection{Implications For Research}

This work has a number of implications for both theory and practice. First, the inclusion and integration of intangible aspects into a cohesive engineering design performance measurement framework extends current theory into the individual/team domain, as explicitly called for by Dewangan and Godse (2014).

Second, the inclusion of dynamic, fine-grain measures extends prior performance measurement theory by integrating dynamic processes and emergent states such as group cohesion (Sivasubramaniam, Liebowitz, and Lackman 2012). This brings together insights from individual and team level literature to complement organisational level measures, fulfilling the 'cascading' multi-level measurement ideal described by Collins and Smith (1999).

Third, the framework proposed in this paper balances intangible fine-grain (e.g. personal characteristics of employees) and traditional tangible coarse-grain (e.g. time and cost) aspects of project management in a multi-dimensional process orientated framework (Gillard 2009). This both moves engineering design performance measurement a step closer the holistic ideal espoused by Dewangan and Godse (2014), and represents one of the first substantive contributions to the fourth generation of design and innovation process focused measurement approaches (Milbergs and Vonortas 2004).

\subsection{Implications For Practice}

With respect to practice, there are three main implications. First, the proposed approach allows for more cohesive performance measurement in engineering design projects across multiple organisational levels. In particular the approach links individual/team level measurement to previously organisation level focused approaches.

Second, the fine-grain dynamic measurement gives a new process perspective for design team leaders and, for the first time, directly incorporates the possibility of realtime assessment of individual/team performance. This brings together leading indicators with traditionally lagging KPI's, and allows dynamic response to changes in engineering design process performance. 
Third, the proposed approach provides a fully operationalized means for monitoring and integrating data from many of the disparate indicators previously only discussed in terms of research variables. This allows for the monitoring of fine-grain performance for the first time. Further, the inclusion of individual/team level measures allows design team leaders to more effectively identify and manage individuals within the wider scope of the design process.

\section{Conclusions}

This work has brought together a comprehensive review of engineering design performance measurement literature to demonstrate a critical gap in prior measurement approaches. Specifically, in the incorporation of dynamic monitoring at the individual/team level. In response we have proposed a new approach to measuring and managing dynamic engineering design work at the individual/team level. This addresses fundamental aspects of design performance measurement, and brings together and operationalizes the previously disperse literature in this area. We integrate fine-grain and dynamic measurement of leading intangible aspects at the individual/team level to realise a fully defined measurement approach and a significant extension of prior theory in the engineering design process performance measurement area.

This work has resulted in a number of implications for practice and further research. First, there is a need to examine the influence of dynamic reaction to individual performance and management decisions with respect to overall project performance. For example, it is possible that an amount of lag in management reaction is desirable. Second, the ability to map process dynamics in real time allows for the identification of archetypal engineering design process performance patterns. This could support both project planning, and the early identification of emergent process features. Also, within the context of engineering work additional intangible aspects should be investigated such as e.g. unsatisfied information/knowledge needs. Finally, the expanded measurement framework proposed here requires further exploration and validation across a range of design contexts. As such, this provides a starting point for integrating 
further fine-grain measurement elements into design process performance measurement approaches.

\section{Acknowledgements}

The study was supported by a grant from the EUREKA program to E!8723 VISINEV project (www.visinev.org) and CSS support to MInMED project (www.minmed.org).

The authors would also like to thank the reviewers for their constructive comments.

\section{References}

Adams, Richard, John Bessant, and Robert Phelps. 2006. "Innovation Management Measurement: A Review." International Journal of Management Reviews 8 (1): 21-47. doi:10.1111/j.14682370.2006.00119.x.

Aisenberg Ferenhof, Helio, Susanne Durst, Mariana Zaniboni Bialecki, and Paulo Mauricio Selig. 2015. "Intellectual Capital Dimensions: State of the Art in 2014." Journal of Intellectual Capital 16 (1). Emerald Group Publishing Limited: 58-100. doi:10.1108/JIC-02-2014-0021.

Alwert, K, M Bornemann, and M Kivikas. 2004. "Intellectual Capital Statement Guideline: Made in Germany." Berlin: Federal Ministry for Economics and Technology. http://www.akwissensbilanz.org/Infoservice/Infomaterial/Leitfaden_english.pdf.

Amabile, T. M. 1988. "A Model of Creativity and Innovation in Organizations." Research in Organizational Behavior 10 (1): 123-67.

Amabile, T. M., R. Conti, H. Coon, J. Lazenby, and M. Herron. 1996. “Assessing the Work Environment for Creativity.” Academy of Management Journal 39 (5): 1154-1184.

Anderson, Neil R., and Michael A. West. 1998. "Measuring Climate for Work Group Innovation: Development and Validation of the Team Climate Inventory." Journal of Organizational Behavior 19 (3): 235-58. doi:10.1002/(SICI)1099-1379(199805)19:3<235::AID-JOB837>3.0.CO;2-C.

Anderson, Neil, and Michael A. West. 1996. "The Team Climate Inventory: Development of the Tci and Its Applications in Teambuilding for Innovativeness." European Journal of Work and Organizational Psychology 5 (1). Taylor \& Francis Group: 53-66. doi:10.1080/13594329608414840.

Artz, Kendall W., Patricia M. Norman, Donald E. Hatfield, and Laura B. Cardinal. 2010. “A Longitudinal Study of the Impact of R\&D, Patents, and Product Innovation on Firm Performance." Journal of Product Innovation Management 27 (5): 725-40. doi:10.1111/j.1540-5885.2010.00747.x.

Aurisicchio, Marco, Rob H. Bracewell, and Ken M. Wallace. 2013. "Characterising the Information Requests of Aerospace Engineering Designers.” Research in Engineering Design 24 (1). SpringerVerlag: 43-63. doi:10.1007/s00163-012-0136-y.

Aurisicchio, Marco, Rob Bracewell, and Ken Wallace. 2009. "Understanding How the Information Requests of Aerospace Engineering Designers Influence Information-Seeking Behaviour." Journal of Engineering Design 21 (6). Taylor \& Francis: 707-30. doi:http://dx.doi.org/10.1080/09544820902877583.

Badke-Schaub, Petra, Andre Neumann, and Kristina Lauche. 2011. "An Observation-Based Method for Measuring the Sharedness of Mental Models in Teams." In Coordination in Human and Primate Groups, 177-97. Berlin, Heidelberg: Springer Berlin Heidelberg. doi:10.1007/978-3-642-15355610 .

Bammens, Yannick P.M. 2016. "Employees' Innovative Behavior in Social Context: A Closer Examination of the Role of Organizational Care." Journal of Product Innovation Management 33 (3): 244-59. doi:10.1111/jpim.12267.

Birdi, Kamal, Desmond Leach, and Wissam Magadley. 2016. "The Relationship of Individual Capabilities and Environmental Support with Different Facets of Designers' Innovative Behavior." Journal of Product Innovation Management 33 (1): 19-35. doi:10.1111/jpim.12250.

Bissola, Rita, Barbara Imperatori, and Renata Trinca Colonel. 2014. "Enhancing the Creative 
Performance of New Product Teams: An Organizational Configurational Approach.” Journal of Product Innovation Management 31 (2): 375-91. doi:10.1111/jpim.12101.

Blindenbach-Driessen, Floortje, Jan Van Dalen, and Jan Van Den Ende. 2010. "Subjective Performance Assessment of Innovation Projects.” Journal of Product Innovation Management 27 (4): 572-92. doi:10.1111/j.1540-5885.2010.00736.x.

Blomqvist, Kirsimarja, and Juha Levy. 2006. "Collaboration Capability - a Focal Concept in Knowledge Creation and Collaborative Innovation in Networks." International Journal of Management Concepts and Philosophy 2 (1): 31-48. doi:10.1504/IJMCP.2006.009645.

Bontis, Nick, and Jac Fitz-enz. 2002. "Intellectual Capital ROI: A Causal Map of Human Capital Antecedents and Consequents." Journal of Intellectual Capital 3 (3): 223-47. doi:10.1108/14691930210435589.

Bozbura, F. T., Ahmet Beskese, and Cengiz Kahraman. 2007. "Prioritization of Human Capital Measurement Indicators Using Fuzzy AHP.” Expert Systems with Applications 32 (4): 1100-1112. doi:10.1016/j.eswa.2006.02.006.

Bozbura, F. Tunc. 2004. "Measurement and Application of Intellectual Capital in Turkey." The Learning Organization 11 (4/5): 357-67. doi:10.1108/09696470410538251.

Bratianu, Constantin, and Ivona Orzea. 2013. "The Entropic Intellectual Capital Model.” Knowledge Management Research \& Practice 11 (2). Nature Publishing Group: 133-41. doi:10.1057/kmrp.2013.11.

Brooking, A. 1997. Intellectual Capital: Core Assets for the Third Millennium Enterprise. Long Range Planning. Vol. 30. International Thomson Business Press.

Cardinal, Laura B., Todd M. Alessandri, and Scott F. Turner. 2001. "Knowledge Codifiability, Resources, and Science-Based Innovation." Journal of Knowledge Management 5 (2): 195-204. doi:10.1108/13673270110393266.

Carley, K.M., and J. Reminga. 2004. "Ora: Organization Risk Analyzer.” CASOS Technical Report, CMU-ISRI-04-106. Pittsburgh PA. doi:10.1.1.150.3888.

Carmeli, Abraham, and Ashler Tishler. 2004. "The Relationships between Intangible Organizational Elements and Organizational Performance." Strategic Management Journal 25 (13): 1257-78. doi:10.1002/smj.428.

Cash, Philip, Ben Hicks, and Steve Culley. 2015. "Activity Theory as a Means for Multi-Scale Analysis of the Engineering Design Process: A Protocol Study of Design in Practice." Design Studies 38: 1-32. doi:10.1016/j.destud.2015.02.001.

Cash, Philip, Ben Hicks, Steve Culley, and Tim Adlam. 2015. "A Foundational Observation Method for Studying Design Situations.” Journal of Engineering Design 26 (7-9). Taylor \& Francis.

Cash, Philip, and Mario Štorga. 2015. "Multifaceted Assessment of Ideation: Using Networks to Link Ideation and Design Activity." Journal of Engineering Design 26 (10-12). Taylor \& Francis: 391415. doi:10.1080/09544828.2015.1070813.

Charnley, Fiona, Mark Lemon, and Steve Evans. 2011. "Exploring the Process of Whole System Design.” Design Studies 32 (2). Elsevier Ltd: 156-79. doi:10.1016/j.destud.2010.08.002.

Chen, Chung-Jen, Tsung-Chi Liu, Mo-An Chu, and Yung-Chang Hsiao. 2014. "Intellectual Capital and New Product Development." Journal of Engineering and Technology Management 33 (July): 15473. doi:10.1016/j.jengtecman.2014.06.003.

Chen, Jin, Zhaohui Zhu, and Hong Yuan Xie. 2004. "Measuring Intellectual Capital: A New Model and Empirical Study." Journal of Intellectual Capital 5 (1): 195-212. doi:10.1108/14691930410513003.

Collins, John, and Darren Smith. 1999. "Innovation Metrics : A Framework to Accelerate Growth." PRism 1st Quarte (First Quarter): 33-47.

Cooke-Davies, Terry. 2002. "The 'real' Success Factors on Projects." International Journal of Project Management 20 (3): 185-90. doi:10.1016/S0263-7863(01)00067-9.

Cruz-Cázares, Claudio, Cristina Bayona-Sáez, and Teresa García-Marco. 2013. "You Can’t Manage Right What You Can't Measure Well: Technological Innovation Efficiency." Research Policy 42 (6). Elsevier: 1239-50. http://econpapers.repec.org/RePEc:eee:respol:v:42:y:2013:i:6:p:12391250 .

Damanpour, F. 1991. "Organizational Innovation: A Meta-Analysis of Effects of Determinants and Moderators." Academy of Management Journal 34 (3). Academy of Management: 555-90. doi: $10.2307 / 256406$.

Dewangan, Vikas, and Manish Godse. 2014. "Towards a Holistic Enterprise Innovation Performance Measurement System.” Technovation $34 \quad$ (9). Elsevier: 536-45. doi:10.1016/j.technovation.2014.04.002.

Dorst, Kees, and Nigel Cross. 2001. "Creativity in the Design Process: Co-Evolution of Problem- 
solution.” Design Studies 22 (5): 425-37. doi:10.1016/S0142-694X(01)00009-6.

Draganidis, Fotis, and Gregoris Mentzas. 2006. "Competency Based Management: A Review of Systems and Approaches." Information Management \& Computer Security 14 (1): 51-64. doi:10.1108/09685220610648373.

Dul, Jan, and Canan Ceylan. 2014. "The Impact of a Creativity-Supporting Work Environment on a Firm's Product Innovation Performance." Journal of Product Innovation Management 31 (6): 1254-67. doi:10.1111/jpim.12149.

Dumay, John. 2014. "Reflections on Interdisciplinary Accounting Research: The State of the Art of Intellectual Capital." Accounting, Auditing \& Accountability Journal 27 (8). Emerald Group Publishing Limited: 1257-64. doi:10.1108/AAAJ-05-2014-1714.

Dumay, John C. 2009. "Intellectual Capital Measurement: A Critical Approach.” Journal of Intellectual Capital 10 (2). Emerald Group Publishing Limited: 190-210. doi:10.1108/14691930910952614.

Dwivedula, Ravikiran, Christophe N Bredillet, and Ralf Müller. 2012. "The Relation between Work Motivation and Project Management Success in Case of Temporary Organizations: Theoretical Lenses." Academy of Business Research 2: 43-66.

Edvinsson, Leif. 1997. "Developing Intellectual Capital at Skandia." Long Range Planning 30 (3): 320 73. doi:10.1016/S0024-6301(97)00016-2.

Ernst, Holger. 2002. "Success Factors of New Product Development: A Review of the Empirical Literature." International Journal of Management Reviews 4 (1): 1-40. doi:10.1111/14682370.00075.

Faure, Corinne. 2009. "Attribution Biases in the Evaluation of New Product Development Team Members." Journal of Product Innovation Management 26 (4): 407-23. doi:10.1111/j.15405885.2009.00668.x.

Fernandes, Kiran Jude, Vinesh Raja, and Andrew Whalley. 2006. "Lessons from Implementing the Balanced Scorecard in a Small and Medium Size Manufacturing Organization." Technovation 26 (5-6): 623-34. doi:10.1016/j.technovation.2005.03.006.

Fuchs, Christoph, and Adamantios Diamantopoulos. 2009. "Using Single-Item Measures for Construct Measurement in Management Research: Conceptual Issues and Application Guidelines." Die Betriebswirtschaft 69 (2): 195-211.

Gallego, Isabel, and Luis Rodríguez. 2005. "Situation of Intangible Assets in Spanish Firms: An Empirical Analysis." Journal of Intellectual Capital 6 (1): 105-26. doi:10.1108/14691930510574690.

Gates, Stephen, and Pascal Langevin. 2010. "Human Capital Measures, Strategy, and Performance: HR Managers' Perceptions." Accounting, Auditing \& Accountability Journal 23 (1): 111-32. doi:10.1108/09513571011010628.

Gillard, Sharlett. 2009. "Soft Skills and Technical Expertise of Effective Project Managers." Informing Science and Information Technology Volume 6: 723-29.

Giuliani, Marco. 2014. "Investigating Intellectual Capital Dynamics: A Field Study." International Journal of Learning and Intellectual Capital 11 (1). Inderscience Publishers Ltd: 20-32. http://www.inderscienceonline.com/doi/abs/10.1504/IJLIC.2014.059225.

González-Loureiro, Miguel, and Pedro Figueroa Dorrego. 2012. "Intellectual Capital and System of Innovation: What Really Matters at Innovative SMEs.” Intangible Capital 8 (2): 239-74. doi:10.3926/ic. 273 .

Gopsill, J, S Jones, C Snider, L Shi, C Mcmahon, and B J Hicks. 2014. "Understanding the Engineering En Gineering Design Process Through the Evolution of Engineering Digital Objects." Proceedings of the 13th International Design Conference DESIGN 2014, 1773-84.

Gopsill, J, C Snider, C McMahon, and B Hicks. 2016. "Automatic Generation of Design Structure Matrices through the Evolution of Product Models.” Artificial Intelligence - Engineering Design and Manufacture In press.

Grant, Maria J., and Andrew Booth. 2009. “A Typology of Reviews: An Analysis of 14 Review Types and Associated Methodologies." Health Information \& Libraries Journal 26 (2): 91-108. doi:10.1111/j.1471-1842.2009.00848.x.

Gries, Bruno, and John Restrepo. n.d. "KPI Measurement in Engineering Design - A Case Study." In $D S$ 68-1: Proceedings of the 18th International Conference on Engineering Design (ICED 11), Impacting Society through Engineering Design, Vol. 1: Design Processes, Lyngby/Copenhagen, Denmark.

Halim, Siana. 2010. "Statistical Analysis on the Intellectual Capital Statement." Journal of Intellectual Capital 11 (1). Emerald Group Publishing Limited: 61-73. doi:10.1108/14691931011013334.

Han, Tzu Shian, Carol Yeh Yun Lin, and Mavis Yi Ching Chen. 2008. "Developing Human Capital Indicators: A Three-Way Approach.” International Journal of Learning and Intellectual Capital 5 
(3/4): 387-403. doi:10.1504/IJLIC.2008.021018.

Haque, Badr, and Mike James-Moore. 2004. Applying Lean Thinking to New Product Introduction. Journal of Engineering Design. Vol. 15. doi:10.1080/0954482031000150125.

Hayton, James C. 2005. "Competing in the New Economy: The Effect of Intellectual Capital on Corporate Entrepreneurship in High-Technology New Ventures." $R$ and D Management 35 (2): 137-55. doi:10.1111/j.1467-9310.2005.00379.x.

Henttonen, Kaisa, Ville Ojanen, and Kaisu Puumalainen. 2016. "Searching for Appropriate Performance Measures for Innovation and Development Projects." R\&D Management 46 (5): 914-27. doi: $10.1111 / \mathrm{radm} .12178$.

Herling, R. W. 2000. "Operational Definitions of Expertise and Competence." Advances in Developing Human Resources 2 (1): 8-21.

Hsu, I-chieh, and Rajiv Sabherwal. 2012. "Relationship between Intellectual Capital and Knowledge Management: An Empirical." Decision Sciences 43 (3): 489-524.

Hsu, Ya-Hui, and Wenchang Fang. 2009. "Intellectual Capital and New Product Development Performance: The Mediating Role of Organizational Learning Capability." Technological Forecasting and Social Change 76 (5): 664-77. doi:10.1016/j.techfore.2008.03.012.

Johanson, U., M. Martensson, and M. Skoog. 1999. "Measuring and Managing Intangibles/eleven Swedish Qualitative Exploratory Case Studies." In International Symposium Measuring and Reporting Intellectual Capital: Experiences, Issues, and Prospects. Amsterdam, Netherlands: OECD.

Ke, Weiling, and Kwok Kee Wei. 2008. "Organizational Culture and Leadership in ERP Implementation." Decision Support Systems 45 (2): 208-18. doi:10.1016/j.dss.2007.02.002.

Kim, L. 1998. "Crisis Construction and Organizational Learning: Capability Building in Catching-up at Hyundai Motor.” Organization Science 9 (4): 506-21. doi:10.1287/orsc.9.4.506.

Kleinsmann, Maaike, Fleur Deken, Andy Dong, and Kristina Lauche. 2012. "Development of Design Collaboration Skills." Journal of Engineering Design 23 (7): 485-506. doi:10.1080/09544828.2011.619499.

Kleinsmann, Maaike, and Rianne Valkenburg. 2008. "Barriers and Enablers for Creating Shared Understanding in Co-Design Projects." Design Studies 29 (4): 369-86. doi:10.1016/j.destud.2008.03.003.

Krackhardt, David. 1999. "The Ties That Torture: Simmelian Tie Analysis in Organizations." In Research in the Sociology of Organizations, Volume 16, 183-210.

Kujansivu, P, and A Lönnqvist. 2007. "Investigating the Value and Efficiency of Intellectual Capital." Journal of Intellectual Capital 8 (2): 272-87.

Leiponen, Aija. 2005. "Skills and Innovation." International Journal of Industrial Organization 23 (56): 303-23. doi:10.1016/j.ijindorg.2005.03.005.

Liu, Jingjiang, Jiyao Chen, and Yi Tao. 2015. "Innovation Performance in New Product Development Teams in China's Technology Ventures: The Role of Behavioral Integration Dimensions and Collective Efficacy." Journal of Product Innovation Management 32 (1): 29-44. doi:10.1111/jpim.12177.

MacBryde, Jill, and Kepa Mendibil. 2003. "Designing Performance Measurement Systems for Teams: Theory and Practice." Management Decision 41 (8). MCB UP Ltd: 722-33. doi: $10.1108 / 00251740310496233$.

Marr, Bernard, Giovanni Schiuma, and Andy Neely. 2004. "The Dynamics of Value Creation: Mapping Your Intellectual Performance Drivers.” Journal of Intellectual Capital 5 (2): 312-25. doi:10.1108/14691930410533722.

Matsumoto, Isao T, John Stapleton, Jacqueline Glass, and Tony Thorpe. 2005. "Developing a Framework to Measure Organizational and Employee Skills Development in a Professional Engineering Design Consultancy." Construction Innovation 5 (1). Emerald Group Publishing Limited: 53-66. doi:10.1108/14714170510815177.

McCarthy, I P, C Tsinopoulos, P Allen, and C Rose-Anderssen. 2006. "New Product Development as a Complex Adaptive System of Decisions." Journal of Product Innovation Management 23 (5): 437-56. doi:10.1111/j.1540-5885.2006.00215.x.

McComb, Christopher, Jonathan Cagan, and Kenneth Kotovsky. 2015. "Rolling with the Punches: An Examination of Team Performance in a Design Task Subject to Drastic Changes." Design Studies 36: 99-121. doi:10.1016/j.destud.2014.10.001.

McMahon, Chris, Alistair Lowe, and Steve Culley. 2004. "Knowledge Management in Engineering Design: Personalization and Codification." Journal of Engineering Design 15 (4): 307-25. doi:10.1080/09544820410001697154.

Milbergs, Egils, and Nicholas Vonortas. 2004. "Innovation Metrics: Measurement to Insight." Center 
for Accelerating Innovation and George Washington University, 7.

Moe, Nils Brede, Torgeir Dingsøyr, and Tore Dybå. 2010. "A Teamwork Model for Understanding an Agile Team: A Case Study of a Scrum Project." Information and Software Technology 52 (5). Elsevier B.V.: 480-91. doi:10.1016/j.infsof.2009.11.004.

Molina-Castillo, Francisco Jose, and José Luis Munuera-Alemán. 2009. "New Product Performance Indicators: Time Horizon and Importance Attributed by Managers." Technovation 29 (10): 714 24. doi:10.1016/j.technovation.2008.11.005.

Montemari, Marco, and Christian Nielsen. 2013. "The Role of Causal Maps in Intellectual Capital Measurement and Management." Journal of Intellectual Capital 14 (4). Emerald Group Publishing Limited: 522-46. doi:10.1108/JIC-01-2013-0008.

Mouritsen, Jan, Per Nikolaj Bukh, and Bernard Marr. 2004. "Reporting on Intellectual Capital: Why, What and How?" Measuring Business Excellence 8 (1): 46-54. doi:10.1108/13683040410524739.

Mulholland, Paul, Zdenek Zdrahal, John Domingue, Marek Hatala, and Ansgar Bernardi. 2001. "A Methodological Approach to Supporting Organizational Learning." International Journal of Human-Computer Studies 55 (3): 337-67. doi:10.1006/ijhc.2001.0494.

Nahm, Abraham Y., Mark a. Vonderembse, and Xenophon a. Koufteros. 2003. "The Impact of Organizational Structure on Time-Based Manufacturing and Plant Performance." Journal of Operations Management 21 (3): 281-306. doi:10.1016/S0272-6963(02)00107-9.

Nonaka, Ikujiro, and Hirotaka Takeuchi. 1995. "The Knowledge-Creating Company: How Japanese Companies Create the Dynamics of Innovation." Oxford University Press. doi:10.1016/S00487333(97)80234-X.

O’Donnell, F. J., and A. H. B. Duffy. 2005. Design Performance. London: Springer-Verlag. doi: $10.1007 / 1-84628-147-4$.

OECD. 2002. Frascati Manual 2002 - Proposed Standard Practice for Surveys on Research and Experimental Development. OECD Publishing. doi:http://dx.doi.org/10.1787/9789264199040-en.

Ojanen, Ville, and Olli Vuola. 2005. "Coping with the Multiple Dimensions of R\&D Performance Analysis." International Journal of Technology Management 33 ((2-3)). Inderscience Publishers: 279-90.

Orr, E., and M. Persson. 2003. "Performance Indicators for Measuring Performance of Activities in Knowledge Management Projects."

Parmenter, David. 2010. Key Performance Indicators: Developing, Implementing, and Using Winning KPIs. John Wiley \& Sons. doi:978-0470545157.

Pinder, C.C. 1998. Work Motivation in Organizational Behavior. Upper Saddle River, NJ: Prentice Hall.

Podsakoff, Philip M, Scott B MacKenzie, Jeong-Yeon Lee, and Nathan P Podsakoff. 2003. "Common Method Biases in Behavioral Research: A Critical Review of the Literature and Recommended Remedies." The Journal of Applied Psychology 88 (5): 879-903. doi:10.1037/0021-9010.88.5.879.

Pollack, Julien. 2007. "The Changing Paradigms of Project Management." International Journal of Project Management 25 (3): 266-74. doi:10.1016/j.ijproman.2006.08.002.

Pulic, Ante. 2000. "VAIC-an Accounting Tool for IC Management." International Journal of Technology Management, 20: 702-14.

Ragab, Mohamed, and Amr Arisha. 2013. "Knowledge Management and Measurement: A Critical Review.” Journal of Knowledge Management 17 (6): 873-901. doi:10.1108/JKM-12-2012-0381.

Redelinghuys, Christiaan, and Terry Bahill. 2006. "A Framework for the Assessment of the Creativity of Product Design Teams." Journal of Engineering Design 17 (2): 121-41. doi:10.1080/09544820500273136.

Reid, Susan E., and Ulrike de Brentani. 2015. "Building a Measurement Model for Market Visioning Competence and Its Proposed Antecedents: Organizational Encouragement of Divergent Thinking, Divergent Thinking Attitudes, and Ideational Behavior." Journal of Product Innovation Management 32 (2): 243-62. doi:10.1111/jpim.12232.

Robinson, Mark A. 2009. "Work Sampling: Methodological Advances and New Applications." Human Factors and Ergonomics in Manufacturing 20 (1). Wiley Subscription Services, Inc., A Wiley Company: 42-60. doi:10.1002/hfm.20186.

_ 2010. "An Empirical Analysis of Engineers' Information Behaviors." Journal of the American Society for Information Science and Technology 61 (4): 640-58. doi:10.1002/asi.21290.

_ 2012. "How Design Engineers Spend Their Time: Job Content and Task Satisfaction." Design Studies 33 (4): 391-425. doi:10.1016/j.destud.2012.03.002.

Sharabati, Abdel-Aziz Ahmad, Shawqi Naji Jawad, and Nick Bontis. 2010. "Intellectual Capital and Business Performance in the Pharmaceutical Sector of Jordan." Management Decision 48 (1): 10531. doi: $10.1108 / 00251741011014481$.

Sim, Siang Kok, and Alex H. B. Duffy. 2003. "Towards an Ontology of Generic Engineering Design 
Activities." Research in Engineering Design 14 (4). Springer-Verlag: 200-223. doi:10.1007/s00163-003-0037-1.

Sivasubramaniam, Nagaraj, S. Jay Liebowitz, and Conway L. Lackman. 2012. "Determinants of New Product Development Team performance:A Meta-Analytic Review." Journal of Product Innovation Management 29 (5): 803-20. doi:10.1111/j.1540-5885.2012.00940.x.

Smith, Dianne, Peter Hedley, and Michael Molloy. 2009. "Design Learning: A Reflective Model." Design Studies 30 (1): 13-37. doi:10.1016/j.destud.2008.06.002.

Snider, Chris, Elies Dekoninck, and Steve Culley. 2016. "Beyond the Concept: Characterisations of Later-Stage Creative Behaviour in Design." Research in Engineering Design 27 (3). Springer London: 1-25. doi:10.1007/s00163-016-0218-3.

Stempfle, Joachim, and Petra Badke-Schaub. 2002. "Thinking in Design Teams - An Analysis of Team Communication.” Design Studies 23 (5): 473-96. doi:10.1016/S0142-694X(02)00004-2.

Suraj, Olunifesi Adekunle, and Nick Bontis. 2012. "Managing Intellectual Capital in Nigerian Telecommunications Companies." Journal of Intellectual Capital 13 (2): 262-82. doi:10.1108/14691931211225724.

Sveiby, K.-E. 2010. "Methods for Measuring Intangible Assets." http://www.sveiby.com/articles/IntangibleMethods.htm.

Syamil, Ahmad, William J. Doll, and Charles H. Apigian. 2004. "Process Performance in Product Development: Measures and Impacts." European Journal of Innovation Management 7 (3). Emerald Group Publishing Limited: 205-17. doi:10.1108/14601060410549892.

Škec, Stanko, Mario Štorga, Zlatka Tečec Ribarić, and Dorian Marjanović. 2015. "Work Sampling Approach for Measuring Intellectual Capital Elements in Product Development Context." In Proceedings of the 20th International Conference on Engineering Design (ICED 2015). Milano, Italy: Design Society.

Takim, Roshana, and Akintola Akintoye. 2002. "Performance Indicators for Successful Construction Project Performance." Vol. 2, 545-55 2 (September): 2-4.

Tan, Hong Pew, David Plowman, and Phil Hancock. 2008. "The Evolving Research on Intellectual Capital." Journal of Intellectual Capital 9 (4): 585-608. doi:10.1108/14691930810913177.

Taylor, Thomas Paul. 2016. "Performance Measurement in Global Product Development: The Selection and Application of Key Performance Indicators.” Technical University of Denmark.

Thamhain, H. 2013. "Managing Risk in Projects." Project Management Journal 44 (2): 20-35. doi:10.1002/pmj.

Turner, Neil, Harvey Maylor, and Juani Swart. 2015. “Ambidexterity in Projects: An Intellectual Capital Perspective." International Journal of Project Management 33 (1): 177-88. doi:10.1016/j.ijproman.2014.05.002.

Valkenburg, Rianne, and Kees Dorst. 1998. "The Reflective Practice of Design Teams.” Design Studies 19 (3): 249-71. doi:10.1016/S0142-694X(98)00011-8.

Van Yperen, Nico W., Burkhard Wörtler, and Kiki M.M. De Jonge. 2016. “Workers' Intrinsic Work Motivation When Job Demands Are High: The Role of Need for Autonomy and Perceived Opportunity for Blended Working." Computers in Human Behavior 60: 179-84. doi:10.1016/j.chb.2016.02.068.

Varlander, S. 2012. "Individual Flexibility in the Workplace: A Spatial Perspective." The Journal of Applied Behavioral Science 48 (1): 33-61. doi:10.1177/0021886311407666.

Verbano, Chiara, and Maria Crema. 2014. "Measuring IC Following a Semi-Qualitative Approach : An Integrated Framework." Intangible Capital 9 (3): 539-58.

Visnjic, Ivanka, Frank Wiengarten, and Andy Neely. 2014. “Only the Brave: Product Innovation, Service Business Model Innovation, and Their Impact on Performance." Journal of Product Innovation Management. doi:doi: 10.1111/jpim.12254.

Vuolle, Maiju, Antti Lönnqvist, and Jacques Van Der Meer. 2009. "Measuring the Intangible Aspects of an R\&D Project." Measuring Business Excellence $13 \quad$ (2): 25-33. doi:10.1108/13683040910961180.

Wang, Wen-Ying, and Chingfu Chang. 2005. "Intellectual Capital and Performance in Causal Models: Evidence from the Information Technology Industry in Taiwan.” Journal of Intellectual Capital 6 (2): 222-36. doi:10.1108/14691930510592816.

Wang, Zhining, Nianxin Wang, and Huigang Liang. 2014. "Knowledge Sharing, Intellectual Capital and Firm Performance." Management Decision 52 (2): 230-58. doi:10.1108/MD-02-2013-0064.

Wasiak, J., B. Hicks, L. Newnes, C. Loftus, A. Dong, and L. Burrow. 2011. "Managing by E-Mail: What E-Mail Can Do for Engineering Project Management." IEEE Transactions on Engineering Management 58 (3): 445-56. doi:10.1109/TEM.2010.2090160.

Wojtczuk-Turek, Agnieszka, and Dariusz Turek. 2015. "Innovative Behaviour in the Workplace: The 
Role of HR Flexibility, Individual Flexibility and Psychological Capital: The Case of Poland." European Journal of Innovation Management 18 (3). Emerald Group Publishing Limited: 397419.

Yang, Xi, Andy Dong, and Martin Helander. 2012. "The Analysis of Knowledge Integration in Collaborative Engineering Teams.” Journal of Engineering Design 23 (November 2012): 119-33. doi:10.1080/09544828.2011.567979.

Yeo, K.T. 2002. "Critical Failure Factors in Information System Projects." International Journal of Project Management 20 (3): 241-46. doi:10.1016/S0263-7863(01)00075-8.

Yin, Yuanyuan, Shengfeng Qin, and Ray Holland. 2011. "Development of a Design Performance Measurement Matrix for Improving Collaborative Design during a Design Process." International Journal of Productivity and Performance Management 60 (2). Emerald Group Publishing Limited: 152-84.

Zika-Viktorsson, Annika, and Sofia Ritzén. 2005. "Project Competence in Product Development." Research in Engineering Design 15 (4): 193-200. doi:10.1007/s00163-004-0051-y. 